\title{
Comparing national approaches to the study of intelligence
}

\author{
Damien Van Puyvelde, James J. Wirtz, Jean-Vincent Holeindre, Benjamin Oudet, Uri \\ Bar-Joseph, Ken Kotani, Florina Cristiana Matei, Antonio Díaz Fernández
}

\section{Introduction (Damien Van Puyvelde and James J. Wirtz)}

The origins of the academic study of intelligence are often traced back to post-Second World War America, to a time when the nuclear revolution fostered the development of the broader field of Strategic Studies (Betts 1997, 9-17; Buzan and Hansen 2009, 66-100). In the United States, Sherman Kent, a Yale University history professor who served with the Office of Strategic Services and helped establish intelligence analysis as a profession at the nascent Central Intelligence Agency (CIA), is often considered as the founding father not only of intelligence analysis but also of intelligence studies. Kent's (1949) Strategic Intelligence for American World Policy, published with Princeton University Press, is often considered as 'the first serious academic study' of intelligence (Scott and Jackson 2004, 140). Kent's academic background and his experience as a practitioner have ensured the continuing relevance of his arguments in some of the core academic debates defining the field today, not the least about the relationship between intelligence and policy. In an article published a few years later in the first edition of Studies in Intelligence - the CIA's inhouse academic journal - Kent (1955) famously emphasised "the need for an intelligence literature". In this essay, the then Director of Training at the Agency stated that a professional literature on intelligence methods and practices would help identify key concepts, and best practices to develop an institutional memory. The first analysts at the CIA thus hoped that benefits might flow from a collaborative relationship between the intelligence and academic communities.

Scholars - particularly historians - did not wait for the Second World War and the subsequent establishment of the CIA to write about intelligence. In his historiography of American intelligence, John Ferris points out that diplomatic historian B. H. Summer, among others, integrated intelligence and diplomacy in his study of Russia and the Balkans published in 1937 (Ferris 1995, 87). The public debate about intelligence in post-War 
America, however, greatly facilitated the discussion of intelligence practices in public outlets (Valero 1993). In the 1950s, a handful of intelligence practitioners (Hilsman 1956; Ransom, 1958) and journalists (Stewart 1953) produced the first book-length studies dedicated to American intelligence (Aldrich 2013). Anglophone historians and political scientists followed their lead, publishing seminal academic journal articles and books on intelligence in the following decades (See for example Wohlstetter 1962; Foot 1966; Andrew 1977; Betts 1978; Ransom 1980).

Three key developments helped structure research on intelligence as an academic field of inquiry in the 1980s. First, higher education institutions in the United States, and then in the United Kingdom, started offering courses on intelligence and integrated intelligence in security and international affairs curricula (Johnson 2014, 4; Phythian 2018: 943-4). Second, scholars started to organise themselves and meet on a regular basis. Scholar Roy Godson launched an 'Intelligence Consortium' and ran a series of training programmes for scholars interested in intelligence studies (Johnson 2014, 5). In 1985, scholars Richard Shultz and Stafford Thomas, helped establish an "intelligence studies section" within the International Studies Association (2019a and 2019b). The section has, since then, organised an annual series of panels and roundtables, providing a common venue for scholars and practitioners of intelligence to present their research, discuss key concepts and cases in intelligence. Third, intelligence researchers launched two scholarly journals in 1986: Intelligence and National Security, and the International Journal of Intelligence and CounterIntelligence. These journals would provide a platform for university researchers and (often former) intelligence professionals to disseminate their research on intelligence across the academic and intelligence communities.

The field gained increasing appeal throughout the 1990s, and started attracting interest from scholars beyond the Anglosphere who helped diversify the pool of cases available for study and comparison, broadening our understanding of intelligence practices (Hastedt 1991; Van Puyvelde and Curtis 2016). Today, intelligence is studied and taught in dozens of universities across the world (Johnson et al. 2017). This diversification raises interesting questions about national approaches to intelligence studies, or modification of common 
intelligence practices to meet local conditions (see Wirtz 2018; Samu 2017). In an increasingly global field, we can no longer assume that there is only one way to think about, study, and teach intelligence as a set of activities and practices that seek to understand and shape international relations and security.

Although it is possible to offer assessments of the nature and scope of intelligence studies in a national context, these assessments inevitably involve comparisons with the situation in other national settings. Intelligence organizations exist to create and protect secrets; outsiders never really gain access to "everything." Thus, if one offers the observation that scholars have "good" access to materials or to intelligence professionals, it can only mean that they have more access to their national intelligence agencies than those working in other countries. Different strategic cultures, historical experiences, and forms of government, however, do create contrasting milieus (Zamand 2009), including when it comes to interaction between scholars and intelligence professionals.

This forum explores intelligence studies in seven countries to assess the extent to which different models of intelligence studies have emerged in the last decades. We decided to focus on France, Israel, Japan, Romania, Spain, the United Kingdom and the United States because these countries have well-established intelligence services and academics interested in the study of intelligence. Examining the state of intelligence studies in France, Israel, Japan, Romania and Spain allows us to go beyond pre-existing comparisons of US and UK approaches and the Anglophone experience (Moran and Muprhy 2013). This comparison also allows us to assess if intelligence studies is expanding to include new empirical and theoretical studies beyond Anglo-centric cases and concerns (Andrew 1977; Herman 1996; Aldrich 2001; Goodman 2007). To facilitate comparison, we have drawn from our experiences as intelligence scholars as well as research on the history of political sciences and security studies in the Anglosphere (Addock, Bevir and Stimson 2009: 1-17; Buzan and Hansen 2009), to identify five dimensions of intelligence studies (see table 1). We posit that these dimensions represent the important factors that shape the development of intelligence as a field of academic enquiry at the national level. Each contributor uses 
this framework to assess the state of intelligence studies in their home countries, utilizing published materials, government documents, and personal experience.

\begin{tabular}{|c|c|}
\hline DIMENSION & QUESTIONS \\
\hline $\begin{array}{l}\text { Access to } \\
\text { information on } \\
\text { intelligence }\end{array}$ & $\begin{array}{l}\text { To what extent do outside researchers have access to } \\
\text { information on government intelligence structures, processes } \\
\text { and practices? What methods do researchers tend to use to } \\
\text { access this information (archives, interviews, etc.)? }\end{array}$ \\
\hline $\begin{array}{l}\text { Institutionalisation of } \\
\text { intelligence studies }\end{array}$ & $\begin{array}{l}\text { How common is it to find intelligence researchers in } \\
\text { Universities and other institutions (research centers, } \\
\text { professional military education, etc.) of higher education? }\end{array}$ \\
\hline Scie & $\begin{array}{l}\text { Have intelligence researchers established a national } \\
\text { association, periodic conferences or meetings? Do dedicated } \\
\text { publication outlets (academic or professional journals, book } \\
\text { series etc.) exist? Have some themes and case studies } \\
\text { dominated the scientific discussions on intelligence practices? }\end{array}$ \\
\hline $\begin{array}{l}\text { Teaching and } \\
\text { learning } \\
\text { opportunities }\end{array}$ & $\begin{array}{l}\text { Do higher education institutions offer courses, diplomas or } \\
\text { degrees on intelligence ? Are these courses focused more on } \\
\text { intelligence education (the role of intelligence in history, } \\
\text { policy-making etc.) or on intelligence training (analytic } \\
\text { tradecraft, etc.)? }\end{array}$ \\
\hline $\begin{array}{l}\text { Relationship between } \\
\text { researchers and } \\
\text { practitioners }\end{array}$ & $\begin{array}{l}\text { What role do serving and former officers play in the four } \\
\text { criteria presented above? How close is the relationship } \\
\text { between practitioners and outside researchers? }\end{array}$ \\
\hline
\end{tabular}

Table 1. Intelligence studies dimensions

The contributions to this forum will be of interest to scholars and practitioners who are keen to develop a more global understanding of intelligence and national security research. At the moment, there is a developing effort within the field of intelligence studies to expand its reach beyond the Anglosphere, and this forum seeks to inform this project. Elements of this discussion will also be relevant to colleagues in the broader discipline of International 
Relations, whose professional career, ability to conduct research, teach and bridge the academic-policy divide, is likely to be shaped by a similar set of factors. In turn, the global character of the contributions to this forum (seven countries across three continents) and the discussion challenges us to think beyond our own national experiences to develop a more comprehensive understanding of the field.

\section{FRANCE (Jean-Vincent Holeindre and Benjaminis Oudet)}

In France, the field of intellignece studies is gaining momentum as a growing number of government and scholarly organizaitons host scholars and practioners to discuss developments in the field. Access to information on government intelligence practices remains limited but this has not prevented a growing number of journals to publish articles on intelligence topics. For the field to move forward, however additional efforts have to be made to provide scholars with the opportunities needed to facilite their scholarly research.

\section{Access to Information on Intelligence}

Access to the archives of core French intelligence agencies such as the foreign and domestic intelligence services (Direction Gérnérale de la Sécurité Extérieure or DGSE, and Direction Générale de la Sécurité Intérieure or DGSI) is regulated by the code du Patrimoine (1978). DGSE archives are available on request from the Historical Defense Service (SHD) created in 2005, and at the National Archives Reception Center (CRAN) for the DGSI. Declassification varies between 25 years (unclassified documents), 50 years (defense and national security records) and 100 years (documents containing names of identifiable intelligence officers). Archives dealing with specifically sensitive issues such as counter-proliferation may remain classified indefinitely. The DGSE archives currently available concern the Bureau Central de Renseignements d'Action or BCRA (the French intelligence services during the Second World War), the French contribution to the decryption of Enigma, and the activities of the ancestor of the DGSE, the Service de Documentation Extérieure et de Contre-Espionnage (SDECE), in Indochina in the early 1950s. The establishment of an Intelligence History Committee within the French 
government's Intelligence Academy in 2019 will allow further debate on access to the archives of services such as Direction du Renseignement Military (DRM) and the Direction nationale du renseignement et des enquêtes douanières (DNRED) that have attracted less attention from academics.

All French services have their own website that presents their key activities and related missions. The Parliamentary Intelligence Delegation (DPR) publishes an annual report and the hearings of heads of services since 2008. The National Commission for the Control of Intelligence Techniques (CNCTR) has also produced an annual public report since 2015. Moreover, since 2006, the documents of the Ministry of Finance and Budget have provided numerous budget and human resources data that were previously inaccessible.

In the last decade, some intelligence services have gradually opened to outsiders, making it possible for the latter to get in touch with community members. For example, The DGSE, the DRM and the financial intelligence unit Tracfin have a set up email addresses so that researchers can contact them and request interviews. This trend toward greater transparency has been supported by a growing body of intelligence legislation, including the passage of a law that has formally established intelligence as a public policy (Assemblée Nationale 2015).

\section{Institutionalization of Intelligence Studies}

French intelligence studies are currently experiencing a second "spring," after their emergence in the late 1990s and early 2000s that was led by historians (see Jackson 2006). The important place given to intelligence in the French strategic doctrines released in 2008, 2017 and 2018 has favored its emergence as a field of study. Nevertheless, in France, no university research center is dedicated to the study of intelligence and therefore, the field remains weakly institutionalized. Researchers are scattered across different disciplines: history, law, political science, linguistic studies, and communication sciences. Twenty-five research centers and universities have contributed to the production of studies on intelligence in France (Holeindre and Oudet 2018). Nevertheless, a number of research 
groups and networks have sought to bring together these researchers. They include a project on the use of technologies related to the interception of communications (UTIC, 2015-2019), and the French Association of Law of Security and Defense (AFDSD) created in 2013. In 2019, the Institute for Strategic Research of the Ministry of Armed Forces (IRSEM) has established a research program on "analysis and anticipation," which is a landmark in the institutionalization of intelligence research in France.

\section{Scientific Debate}

Scientific discussions about intelligence practices take place in a limited number of seminars, most of which take place in Paris. The METIS seminar series, hosted by the History Center at Sciences Po Paris, has held meetings since 2008 and gathered practitioners, former practitioners, academics, and young scholars. The Association pour les Etudes sur la Guerre et la Stratégie (AEGES), estbalished in 2017, has a working group on intelligence, which organises half a dozen events a year. These two initiatives, among others, have provided a platform for researchers and practitioners to debate intellgience organisations and practices.

French intelligence studies projects have found a home in a growing number of journals including Après-Demain, Criminologie, Culture et Conflits, Défense et sécurité internationale, Hermès, Les Cahiers de la sécurité et de la justice, Les Champs de Mars, Politique Internationale, Questions internationales, Revue internationale et stratégique, and Stratégique. Although the number of publications is growing, they remain as fragmented as the field of study. And academic research on intelligence has not yet been published in the most influential political science and public administration journals such as the Revue française de science politique (RFSP) and the Revue française d'administration publique (RFAP).

Public institutions' support for intelligence studies is a strong vector of institutionalization, which can help the academic debate to flourish. The government's Intelligence Academy sponsored conferences in 2016 (history) and 2018 (law) that favored the development of 
publications (Forcade and Vaïsse 2019). In 2019, the Intelligence Academy began awarding scientific prizes for a doctoral dissertation as well as a work of fiction (book, documentary, movie). Similarly, the French Parliament organizes meetings between academics and practitioners. The latest meeting, in 2019, focused on the role of intelligence in countering terrorism financing. The intelligence community also has sought to raise awareness about intelligence structures and practices in the state itself, particularly among future leaders enrolled in courses at the Ecole nationale d'administration (ENA) and the Ecole nationale de la magistrature (ENM).

\section{Teaching and Learning Opportunities}

Undergraduate and graduate students are increasingly interested in intelligence issues and keen to take specialized courses offered in political science, international relations, public affairs and strategic studies curricula. This trend is illustrated by the diversity of courses offered at the master's level at Sciences Po Paris' School of International Affairs, the Universities of Bordeaux Montesquieu, Lille II, Lyon III and Sciences Po Lyon. The multiplication of courses has favored the publication of textbooks such as l'Atlas du renseignement (Laurent 2014), Leçons sur le renseignement (Cousseran and Hayez 2017), Renseignement et Sécurité (Chopin and Oudet 2016). Former senior intelligence and security officials Jérôme Poirot and Hugues Moutouh (2018) have recently edited a dictionary on intelligence. The latest collective work, which brings together academics and practitioners, is paving the way for further cooperation between the two communities.

Traditionally, the services have taken charge of training their personnel and universities were not considered as a place for initial or pre-training. Nevertheless, this situation is changing and the Intelligence Academy has recently established (May 2019) a new diploma on "Intelligence and global threats" together with Sciences Po Saint-Germain-enLaye. This diploma will bring together cohorts of students and practitioners.

\section{Relationship Between Researchers and Practitioners}


The development of intelligence as a strategic function of the French state has resulted in the constitution of a network of academics who meet periodically in seminars. In June 2018, and for the first time in an academic context, METIS organized a meeting with the six heads of the French intelligence services and the national coordinator for intelligence and the fight against terrorism (CNRLT). These officials used this opportunity to present their views on the creation, renewal, and strengthening of the links between the services and the academy. Similarly, the seminar of the intelligence working group within the Association for the Study of War and Strategy (AEGES) has organized a dozen meetings since 2016 with former practitioners and academics who discuss their experience and present their research.

Relationships between researchers and practitioners can form at the service's request when an academic is working on an issue of direct interest to intelligence activities. The DGSE has established an internal think tank named "Interaxions," which organizes periodic meetings and has published the results of events on Daesh, African Islam and the Western Balkans for example (Ministère des Armées 2019). The DRM has established a partnership with the Centre national de la recherche scientifique (CNRS).

The Intelligence Academy also promotes meetings by integrating researchers into the training cycles of practitioners. It also organizes more informal meetings called the "Academy's breakfast," during which researchers can present and discuss their work with practitioners. Exchanges also take place within hybrid research structures such as the IRSEM. This was the case in December 2018 with the organization of a joint conference between IRSEM and DGSE's "Interaxions" on the development of intelligence studies. The National Institute of Higher Studies on Security and Justice (INHESJ) organizes similar events related to domestic security issues. While these conferences do not focus specifically on intelligence matters, they act as a platform for intelligence practitioners and scholars to meet and exchange knowledge on topics such as counter-terrorism and cybersecurity, which are directly relevant to the intelligence services. 
Relations between researchers and practitioners are on a positive trajectory in France. They are likely to strengthen thanks to the creation of exchanges hubs sponsored by the government, at the Intelligence Academy and beyond, and the diversification of bilateral links between each service and higher education institutions.

Over the last ten years, French intelligence studies have benefited from a favorable political and intellectual environment. Nevertheless, six potential developments would strengthen intelligence studies in France. First, intelligence should be considered as a "normal" research subject in the social sciences. If intelligence is a specific activity, it is now regarded as "public policy" in France since the 2015 law. As such, it can be studied thanks to standard research methodologies. Second, these studies must be part of the academic disciplines recognized by the national university council (CNU) to strengthen their legitimacy. These include political science, law, sociology, history, but also crosscutting research areas such as war studies or strategic studies. These studies must respect the same scientific requirements as other established fields of study so as not to appear as a mouthpiece for the intelligence services. Maintaining this distinction is essential to demonstrate that researchers in intelligence studies are not spies. Third, the field needs a specialized French-language journal that follows the best standards of academic publications such as the double-blind peer review process. Fourth, the intelligence services should promote the recruitment of PhDs, which is already the case at the DGSE and the DRM. Some intelligence agencies are currently discussing the issue of funding postgraduate students and the integration of $\mathrm{PhDs}$ into career paths for intelligence officers. Fifth, academic researchers should be granted security clearances and permitted to serve on an ad hoc basis within the intelligence services. The presence of researchers in the services can be justified by their academic background and expertise on specific topics. Ideally, researchers wishing to undertake doctoral or post-doctoral research on issues that are relevant to the services should be eligible for temporary accreditation or authorization to access archives. Sixth, intelligence studies in France cannot develop independently from international research programs. French researchers must participate more in international conferences such as the annual convention of the International Studies Association (ISA) so that French studies do not flourish in an "insular" way. 


\section{ISRAEL (Uri Bar-Joseph)}

Intelligence studies in Israel do not reflect the central role of intelligence in the state's national security doctrine. A strong intelligence community capable of providing a highquality warning against an all-out Arab conventional surprise attack has been one of the main pillars of Israel's security doctrine since the state was born. Accordingly, Israel has built over the years a robust intelligence community at the center of which are three organs: Military Intelligence (Aman), foreign intelligence (the Mossad), and the General Security Service (Shabak). The fact that Israel has repeatedly been engaged in conflict over its history (Maoz 2006) gave the country's intelligence community a special status and role, unlike other western democracies. Consequently, the Israelis consider the intelligence community as the nation's first line of defense. Service in the community is regarded as an important and a patriotic mission.

The stunning military victory in the June 1967 War, when the Israel Defense Force (IDF) defeated the armies of Egypt, Syria, and Jordan and occupied the Sinai, the Golan Heights, and the West Bank in six days, rested on excellent intelligence information that facilitated the destruction of the of the Arab airpower in the war's first hours. Six years later, a major intelligence warning failure led the IDF to its gravest defeats in the Sinai and the Golan fronts during the first days of the Yom Kippur War of October 1973, creating a major threat to the state's security. Today that failure is still considered the most traumatic event in Israeli history. Since the decline in the magnitude of the Arab conventional threat in the 1980s, the intelligence community has played a prime role in meeting other challenges, be it the Iraqi, Iranian and Syrian attempts to build up nuclear arms, Palestinian and Islamic terrorism, or Hezbollah's accumulation of a huge ballistic arsenal, which currently constitutes the main threat to Israel's security.

Nevertheless and despite the fast development of intelligence as a subject of academic studies in other countries, especially in the United States and the United Kingdom, 
intelligence studies did not flourish in Israeli academia and in most of Israel's leading universities intelligence studies has remained a relatively marginal subject.

\section{Access to Information on Intelligence}

Given its important role in Israeli daily life and history, the state's intelligence community has been the subject of many studies by Israeli and foreign researchers (Black and Morris 1991; Katz 1992; Raviv and Melman 2014; Gilboa and Lapid 2012; Thomas 2015; Bergman 2018). Most of these studies, however, do not rely on original documents due to national security concerns. According to Israel's Archives Law of 1955, the documents of the General Security Service, the Mossad, Israel Atomic Energy Commission, Israel Institute of Biological Research, and various units of the Ministry of Defense and Israel Defense Force (IDF), including Military Intelligence, remain closed for fifty years (Israel Archives Law 1955, 21). In 2010, Prime Minister Benyamin Netanyahu extended this period to 70 years and shortly before Israel's $70^{\text {th }}$ anniversary he extended it to 90 years (Ravid 2010; Israel Defense 2019).

Scarce archival material concerning Military Intelligence, mainly in the form of intelligence summaries, has been released over the years by the IDF and the Ministry of Defense Archive. The protocols of the IDF General Headquarters (GHQ) weekly meetings until the end of the 1960s have been released as well. Most of them include a weekly intelligence summary that was presented by the Director of Military Intelligence at the beginning of each meeting. Until 1974 Military Intelligence was Israel's sole national intelligence estimator. Consequently, the summaries in the GHQ meetings provide an opportunity to follow intelligence estimates not only in military issues, but in all aspects relevant to Israel's national security (Israeli Ministry of Defense 2019).

The main exception to the archival void in intelligence documentation is the 1973 Yom Kippur War. The IDF's surprise at the beginning of that war can be linked to a warning fiasco. Therefore, the performance of the community, especially Military Intelligence, was the focus of the war's official investigation, known as the Agranat Commission. The 
Commission produced three reports: a short heavily sanitized one, which contained its main conclusions, was released in 1974, and two additional and detailed reports were released thirty years later (State of Israel 1974 and 1975). In addition, the testimonies of the 58 witnesses that appeared before the commission during its secret hearings, including several high-ranking officers in Military Intelligence and the Mossad, were released as well, and additional documents about the war continue to become public (Israel Ministry of Defense Archives 2019). Nevertheless, political pressures put limits to the process. In 2013, the Israel State Archive prepared an important selection of documents for release, which contained, among other things, the agendas of Prime Minister Golda Meir's cabinet, the government meetings, and the Prime Minister's meetings throughout the war. For reasons that remain classified, Prime Minister Benyamin Netanyahu vetoed their release.

The gap created by the lack of archival sources and the need to document Israel's stormy intelligence history has been bridged mostly by interviews with retired or active service intelligence officers and through the use of the memoirs of veteran intelligence officers. These sources are rather problematic. The reliability of interviews, either because they were conducted by non-experts, or due to motivated and unmotivated biases of the interviewees, or both, can be highly doubtful. Memoirs by Israeli veteran intelligence officers are, in many cases, highly biased and are often used to settle accounts with rivals rather then being underaken with an eye towards doing justice to history. In the 1980s, for example, the Mossad chief, Isser Harel, published several books aimed at demonstrating that in a series of controversies between the Mossad and Military Intelligence during his tenure (1951-1963), Military Intelligence was wrong (Harel 1980). Similarly, the Director of Military Intelligence in the Yom Kippur War, Maj. Gen. (ret.) Eli Zeira (1993), published his version of the events that led to the warning failure, blaming the Mossad for the fiasco. As we know today, the memoirs of both Harel and Zeira were highly biased and quite misleading, although they both included significant and reliable nuggets of information about the performances of Military Intelligence and the Mossad in the early 1960s and prior to the 1973 war. 
As a result of the limits on the use of archival material, documented histories of Israel's intelligence community hardly exist. The main exceptions are two in-house histories - one of the pre-state services and the other about the establishment of the community during the War of Independence - and a study of the history of the first decade of Military Intelligence (Gelber 1992; Gelber 2000; Siman Tov and Hershkovitz 2013).

\section{Institutionalisation of Intelligence Studies}

The contradiction between the rich history of Israel's intelligence agencies and the poor state of its documented history also is evident in the gap between the significant role of academia in the buildup of the community and the poor role that intelligence studies play in current academic curricula when compared to other countries such as the United States and the United Kingdom.

Historically, strong ties between academia and the intelligence services originate to the pre-state Jewish Yishuv, where students of the department of Islamic and Middle Eastern studies in the Hebrew University, which was established in the 1920s, constituted the nucleus of professional intelligence research on the neighboring Arab states. One of the students was Yehoshafat Harkabi, who in 1955 became the Director of Military Intelligence and is considered to be the intellectual father of this organization. During the late 1950s and early 1960s, Harkabi gave an annual series of lectures in the course for senior intelligence officers about national intelligence. The lectures, which followed the route paved by Sherman Kent's Strategic Intelligence for American Foreign Policy (1949) were recently published as a book (Harkabi 2015).

Since its establishment, Military Intelligence has maintained a high level of cooperation with the Middle East experts of the Hebrew University. Its first course for senior intelligence officers was conducted in coordination with the university, some of its courses were taught by its professors in military settings while others were given at the campus. In the mid-1960s, the center of intelligence-academic cooperation moved to the newly established Shiloah Institute (today the Moshe Dayan Center) at Tel Aviv University. As 
part of this cooperation, professors of the Institute made their reserve military service in Military Iintelligence Research Department and regularly took part in its professional discussions. Military Intelligence also shared its collection from open sources with the Shiloah Institute (Lapid 2017).

In 2004, Military Intelligence initiated an academic program aimed at training high-school graduates to become intelligence officers in various positions. Known as "Havatzalot" (sand-lilies) it has become Military Intelligence's most prestigious program. It consists of 25-40 distinguished students who are selected annually and study in a specially constructed first-degree program. Until 2018, they studied at Haifa University and since then at the Hebrew University. Their curriculum is made of core courses in Arabic, Middle Eastern studies and political science as well as electives in sociology, psychology, philosophy, and mathematics. During their academic studies, the students also take military courses, including officer training, and practice in intelligence work.

\section{Scientific Debate}

The contribution of Israeli academicians to the development of the field of intelligence studies, especially during the 1980s, was noticeable. Michael Handel, who taught at the Hebrew University until the mid-1980s, established in 1986 together with Christopher Andrew of Cambridge University, the first academic journal in the field, Intelligence and National Security. In addition to original and important contributions to the creation of intelligence theory, Handel also conducted a series of professional conferences at the US Army War College in Carlisle, Pennsylvania, which yielded excellent edited volumes on topics such as leaders and intelligence and intelligence and deception (Handel 1987 and 1988). Two other Israeli scholars made important contributions to the study of surprise attack: Ephraim Kam, who focused on the causes for the victim's failure to obtain a highquality warning prior to the attack, and Ariel Levite, whose Ph.D. dissertation yielded

original theoretical conclusions from comparing the American warning failure in Pearl Harbor to the success in the battle of Midway (Kam 1988; Levite 1987). Unfortunately, 
they left no sequel to these works in Israeli academia. Handel stayed in the United States and Kam and Levite embarked on a governmental rather than an academic career.

\section{Teaching and Learning Opportunities}

Despite its centrality to the state's national security, there are no intelligence studies centers in Israeli universities. There is no intelligence studies section in the Israeli Association for International Studies. Nevertheless, courses on intelligence have been taught since the early 1990s in several academic institutions. The courses offered include: Intelligence and National Security; Surprise Attack: Barbarossa, Pearl Harbor, and Yom Kippur (Uri BarJoseph, Haifa University, Tel Aviv University); Intelligence, War, and International Relations: The $20^{\text {th }}$ Century Experience; The Surprise of Yom Kippur (Yigal Sheffi, Tel Aviv University, Tel Hai College); Intelligence Research; Covert Operations (Ephraim Kahana, Western Galilee College); Intelligence Services in the World (Shlomo Shapira, Bar-Ilan University). Notably, unlike first degree students in most other countries, many Israeli students start their academic studies after a three-year regular military service, sometimes in the intelligence corps. Consequently, they are more familiar with the practical aspects of intelligence work than most of their counterparts in western democracies.

\section{Relationship Between Researchers and Practitioners}

The role of retired intelligence officers in academic institutions is rather limited, altbough they are more active in non-academic research centers. The Institute of National Security Studies (INSS 2019), which originated as an academic institute at the Tel Aviv University in 1983 but later became independent, counts intelligence as one of its specializations. It also produces the e-journal Cyber, Intelligence, and Security. Notably, of the six persons who headed the institute since its establishment, one was a retired diplomat, two were academicians, and three were retired IDF officers. Before retirement the three served either as Directors of Military Intelligence (Maj. Gen. (ret.) Aharon Yariv and the current head, Maj. Gen. (ret.) Amos Yadlin) or in a senior intelligence position, (Brig. Gen. (ret.) Zvi Shtauber). 
Israel Intelligence Heritage and Commemoration Center (IICC 2019) is a state institute dedicated to the memory of the casualties of Military Intelligence, the Mossad, the General Security Service, and Nativ (a once-clandestine organization that aided in the rescue of Jewish communities in peril). The center also conducts various activities aimed at commemorating the contribution of the intelligence community to Israel's security. It also publishes a bi-annual periodical containing articles on various aspects of the history of the intelligence community.

In addition, the IICC has two semi academic centers. The Meir Amit Intelligence and Terrorism Information Center (ITIC) conducts research and analysis on Middle Eastern affairs in general and terrorism-sponsoring countries Iran and Syria in particular. It also specializes in current Palestinian affairs. It publishes two periodicals: News on Terrorism and the Arab-Israeli Conflict and Spotlight on Iran, which are issued in eight languages, including Farsi and Arabic (Intelligence and Terrorism Information Center 2019a and 2019b). The ITIC's library, which is opened to the public, houses about 17,000 books as well as many other items on intelligence, terrorism and Middle Eastern affairs. It is the best library of its kind in Israel.

In 2016 the IICC launched a new endeavor, The Project for the Study of Intelligence Methodology. It is staffed by retired and active duty intelligence officers and is headed by Brig. Gen. (ret.) Yossi Kuperwasser, a former head of the Research Department of Military Intelligence. The project is built on the assumption that intelligence practitioners are the best at developing relevant knowhow and methodology for the community's organizations. The project issues a bi-annual periodical enitled Intelligence Theory and Practice (Intelligence and Terrorism Information Center 2019c).

\section{JAPAN (Ken Kotani)}

The study of intelligence has traditionally been approached as a part of the diplomatic and military history of Japan. Japanese historians have paid specific attention to the role played 
by signals intelligence (SIGINT) during the Washington naval conference of 1922, the Pearl Harbor attack (1941) and the battle of Midway (1942). The case of Pearl Harbor has attracted the most attention, possibly because of broader debates in the field and the availability of some American and British SIGINT records on the topic. Some of the American revisionists' literature on the Pearl Harbor attack also was translated into Japanese (see Toland 1982; Morgenstern 1999; Stinett 2001; Beard 2011).

The role played by historians in the establishment of intelligence studies in Japan can be linked to the influence of British scholars, who played an important role in training Japanese historians. Terumasa Nakanishi, a professor at Kyoto University, studied intelligence at Cambridge University where he pursued research under Sir F. Harry Hinsley, the official British historian of the Second World War. Inspired by this approach, Nakanishi $(2007,11)$ writes that the "study of intelligence history should be based on many official intelligence documents, that secure the quality of the study." Nakanishi has influenced younger generations of researchers and the Japanese approach to intelligence studies, which largely focuses on historiography and is shaped by the availability of archival records.

Japanese scholars recently started to consider intelligence studies as a part of international relations and national security studies. For the longest time, students who were interested in intelligence and international relations had no choice but to read a translation of Sherman Kent's seminal monograph Strategic Intelligence for American World Policy. Then, in 2003, Hajime Kitaoka (2003), a former senior intelligence official, authored the first intelligence textbook in Japanese.

\section{Access to Information on Intelligence}

Japanese historians have struggled to access information on the conduct of government intelligence activities. In the case of the Second World War, the Japanese Army and Navy systematically destroyed most of their intelligence records at the end of the conflict. As a result, there is a misperception that the Army and Navy intelligence sections did nothing 
during WWII. Nevertheless, fragmentary sources and documents that survived in the Diplomatic Archives of the Ministry of Foreign Affairs (MOFA) and the Military Archives of National Institute for Defense Studies (NIDS) suggest otherwise. Military historian Tsutao Ariga (1994), a former Colonel in the Japanese Air Self-Defense Force, exploited intelligence documents of the NIDS to write a book entitled The Intelligence organizations and operations of the Japanese Army and Navy. His monograph was the first academic book focusing on Japanese intelligence history. The MOFA and NIDS archives also hold fragmentary SIGINT records (Tokushu Joho) of the Second World War, which are available on the website of Japan Center for Asian Historical Records (Japanese National Archives 2019; Kotani 2011). This website, which holds the MOFA and NIDS records and the National Archives of Japan, is now accessible in Japanese, English, Chinese and Korean languages.

Researching post-WWII Japanese intelligence history remains extremely complex, not least due to the secrecy of intelligence activities. Because of a lack of official documents, no historian has ever written a comprehensive history of Japanese intelligence. The Cabinet Intelligence Research Office (CIRO), Ministry of Foreign Affairs, Ministry of Defense (MoD), National Police Agency (NPA) and Public Security Intelligence Agency (PSIA) have not opened their post-WWII records. They are not legally obliged to pass their documents to the National Archives of Japan and this situation has prevented researchers from writing about Japan's post-WWII intelligence history. This situation has pushed Japanese intelligence researchers to rely on oral history to collect information from serving or retired intelligence officers. Newspaper articles from the Sankei Shimbun, and the proceedings of the National Diet (2019), Japan's legislature, which record a large number of debates and speeches by politicians and government bureaucrats, can help fill in some of the blanks.

\section{Institutionalization of Intelligence Studies and Scientific Debate}

There are very few intelligence scholars at universities and research institutions in Japan. The Japan science and technology agency (2019) runs a website that maps researchers by 
topic. Nine individuals are currently registered as "intelligence researcher" on this website. In 2002 Professor Nakanishi established the Association of Intelligence History Studies (2019) and started to publish an annual periodical: the Review of Intelligence History. The association has held intelligence studies seminars five to six times a year since 2002. Most of the participants to this seminar series are Japanese intelligence historians and in the past, retired senior officials such as former Foreign Minister Nobutaka Machimura, former chief of CIRO Yoshio Omori, and MOFA officer Hajime Kitaoka, have joined the seminar. Several western intelligence researchers, such as Michael Herman, Antony Best, Douglas Ford and Nicholas Eftimiades have also been invited to the seminar as guest speakers. Since 2003, the Institute of $20^{\text {th }}$ Century Media (2019) at Waseda University also publishes an annual periodical entitled Intelligence and holds an annual convention. One of the conveners of this Institute, Professor Taketoshi Yamamoto, wrote several books on Japanese Army's intelligence operations during WWII (Yamamoto 1998, 2013, 2017).

Journalism is one of the main pillars of Japan's intelligence studies and several well-known Japanese journalists have published books on intelligence. One pioneer, Mikio Haruna, a former news deputy editor at the Kyodo News Service, wrote a book entitled Secret Files: CIA's Clandestine Operations in Japan, which explores the CIA's anti-communist operations in Japan during the Cold War (Haruna 2000). Haruna is also an active participant to the seminar series organized by the Institute of $20^{\text {th }}$ Century Media. He gives lectures on intelligence at the graduate school of Waseda University. In 2006, Ryuichi Teshima, ex-Washington Bureau Chief for NHK news, and Masaru Sato, an former senior analyst at the International Intelligence Bureau of the Ministry of Foreign Affairs coauthored a book, Intelligence: war without weapons, that became a best-seller in Japan (Teshima and Sato 2006). 230,000 copies of the book were sold in two months and, as a result, the English word "intelligence" used in the book's title became widely used in Japan. The book had a significant impact on Japanese people and popularized the study of intelligence.

\section{Teaching and Learning Opportunities}


A number of Intelligence Studies textbooks are now available in Japanese, helping to make the subject accessible to Japanese students. The first of these textbooks, Intelligence creation, was published by Hajime Kitaoka (2003), a serving diplomat of the MOFA with a background in intelligence. Kitaoka's book explores the practice of intelligence analysis in a way that is comparable to the efforts of some American authors (see for example Clark 2012). In 2011, National Police Agency officer Yoshiki Kobayashi published a textbook on the Fundamentals of Intelligence, which provides an introduction to the intelligence cycle, the Japanese intelligence community, the practices of intelligence collection, analysis, counter-intelligence and oversight. The following year saw the publication of another textbook entitled Intelligence: How states manage intelligence (Kotani 2012). In addition, seminal American texts such as Sherman Kent's Strategic Intelligence and Mark Lowenthal's Intelligence: From Secret to Policy have been translated into Japanese. The Japanese translation of Lowenthal's textbook, first published in 2011, was undertaken by former director of the International Intelligence Bureau at the Ministry of Foreign Affairs and former ambassador to Israel Hiroshi Shigeta, together with a team of nine active diplomats. The book is widely read by Japanese intelligence officers and university students interested in national security.

Only a handful of universities offer intelligence studies courses in Japan. Nihon University (private) offers an intelligence course to undergraduate students at its College of Risk Management. Three other institutions, the National Defense Academy, Aoyama Gakuin University (private) and Waseda University (private) offer intelligence studies classes as a part of international relations and security studies at their graduate school. Japanese Universities are strongly attached to pacifist ideals and have been reluctant to offer courses and programs on military, security and intelligence affairs (Nihon Gakujyutsu Kaigi 2017). The limited development of Intelligence Studies in university curricula prevents postgraduate students from underttaking research on intelligence issues. Given this lack of opportunity, a number of emerging scholars have decided to pursue intelligence studies abroad. 
As far as job opportunities are concerned, the CIRO recruits 3 to 7, and the PSIA recruits 50 to 80 new intelligence officers annually (Japanese Cabinet Office 2019a and 2019b). The MoD, MOFA and NPA do not directly recruit intelligence officers, but hire new graduates and then assign some of the most talented ones to intelligence positions. Most of these recruits do not have experience studying intelligence, and they usually take the joint intelligence training course managed by CIRO (Japanese Prime Minister's Office 2019). The PISA, MoD, MOFA and NPA also have their own introductory training course on intelligence.

\section{Relationship between Researchers and Practitioners}

During the Cold War, the academic study of intelligence was limited to a small circle of historians. In this context, former practitioners and journalists provided the most significant contribution to the development of intelligence studies, most often through the publication of memoirs. A number of officers wrote their memoir after they retired. Others became interested in the study of intelligence when taking courses abroad - mostly in the United States and the United Kingdom - and published works on intelligence while they were still serving in government positions.

Several retired Japanese army and navy officers wrote their memoirs after WWII. For example, retired Colonel Ichiji Sugita (1987), the US section chief of the intelligence bureau of the Army General Staff, published War Leadership without Intelligence and retired captain Yuzuru Sanematsu (1980), the US section chief of intelligence bureau of the Navy General Staff, authored The US-Japanese Intelligence War Diary. The Nakano School Alumni Society published a semi-official history entitled The Nakano School, which examined the eponymous Japanese Army's spy school (Nakano Koyuukai 1978). This book provides a detailed account of covert operations undertaken by the Japanese Army during the Second World War.

Most of the Japanese intelligence officers who served during the Cold War believe that their mission requires them to keep silent about their activities even after their retirement. 
As a result, formers intelligence officers usually refuse to interact with outsiders, preferring to carry their secrets to the grave. One notable exception is the memoir of Hisahiko Okazaki (1980), a former director of the international intelligence bureau of the MOFA. This reluctance to share information has gradually changed since the beginning of the twentyfirst century when government officials started to realize the importance of keeping historical records. Former CIRO director Yoshio Omori (2005) and Vice-Admiral Fumio Ota (2005), the former director of the Defense HQ, have both published their memoirs. Although ex-intelligence officers of the National Police Agency tend to keep silent, a number of former police officers have written books on intelligence operations, including Atsuyuki Sassa (2016) and Jun Yoshino (2016).

Ex-military intelligence officers tend to be more open about their experiences and have written more extensively about intelligence. In 2010, retired Major General Hiromichi Hirajo, the former section chief of the Second Bureau of the Ground Staff Office, for example, revealed the existence of a secret covert operations section of the Japan Ground Self Defense Force (Musashi Kikan). Lieutenant (retired) Morio Sato (2012), a Russian language specialist of the Second Bureau, wrote a book entitled Lessons of Intelligence War. Sato had first-hand experience eavesdropping on Soviet Air force communications during the Korean Airlines flight 007 incident that occurred in September 1983. Sato's book revealed Japan's SIGINT operations against the Soviet Union during the Cold War. Sato has also agreed to share his experience with a number of historians. Former military officers also have contributed to the more applied literature on intelligence. For example, Atsumori Ueda (2016), a former lieutenant colonel and analyst at Defense HQ, published a textbook on intelligence analysis.

In the twenty-first century, intelligence professionals became interested in teaching intelligence and publishing on the topic. Hajime Kitaoka of the MOFA published several textbooks on intelligence. He also participates in academic seminars at universities in Japan. Yoshiki Kobayashi (2015a and 2015b) has presented papers at academic conferences and shares information with academic researchers despite the fact that he is an active senior intelligence analyst for CIRO. He also has lectured on intelligence at Keio 
University and at the National Defense Academy of Japan. Although serving practitioners like Kobayashi are not allowed to share secret information with outsiders, their views on intelligence help academic researchers to understand current intelligence practices.

Much like in Western countries, historians, bureaucrats and journalists have played a central role in the development of intelligence studies in Japan. Nevertheless, the development of intelligence studies has been slower and more limited in Japan than in the United Kingdom and the United States. Japanese academia remains influenced by liberalism, and scholars have paid little attention to intelligence organizations and practices. In Japan, many historians continue to regard intelligence studies as an obscure field defined by conspiracy theories. Despite this prevailing attitude among scholars, bureaucrats and journalists have helped fill in gaps in our knowledge about intelligence in Japan. Their efforts, and the efforts of a handful of historians, have gradually helped intelligence studies become more recognized in Japanese academic circles over the last 10 years.

\section{ROMANIA (Florina Cristiana Matei)}

Since its transition to democracy in December 1989, Romania has worked to transform its intelligence education, through the adoption of new education-related laws, policies, programs, and institutions, as part of a more comprehensive effort to remove the stigma of the former communist intelligence apparatus and professionalize its new intelligence community (Matei 2014a; Maior 2012; Filip and Ştefureac 2011; Dumitru 2014). ${ }^{1}$ For example, The Romanian Intelligence Service (SRI)'s National Intelligence Academy (ANI) educates and trains active duty and reserve SRI officers as well as intelligence

\footnotetext{
${ }^{1}$ There are six intelligence agencies operating in Romania: the Romanian Intelligence Service (SRI); the Foreign Intelligence Service (SIE); the Guard and Protection Service (SPP); the Special Telecommunication Service (STS); the Directorate for Intelligence and Internal Protection (DIPI); and the Directorate for General Information of the Armed Forces (DGIA). In addition, there is a National Intelligence Community, and a "Center for Situations" in the Prime Minister's chancellery.
} 
personnel from other Romanian national security organizations. ${ }^{2}$ Likewise, the SRI's Gradistea and Bran Training Centers provide specific intelligence training for those intelligence community personnel hired from among graduates of civilian universities (Timofte 2003, 63-69). The Ministry of Interior's Police Academy provides undergraduate, graduate and postgraduate education for police personnel, and other national security system personnel (including intelligence professionals). ${ }^{3}$ The various academies and centers of education and training of the Romanian armed forces - including the Military Academy and the Technical Military Academy - also provide education to military intelligence officers, as well as other intelligence personnel. Within this context, Romania has made progress in overhauling the study of intelligence, primarily due to the intelligence agencies'-in particular SRI's - efforts to foster an intelligence culture, coupled with an emergent-albeit modest-public interest in learning about security, intelligence and defense matters (Matei 2014; Filip and Ştefureac 2011; Dumitru 2014; Maior 2012). Notwithstanding this remarkable progress in the "democratization" of intelligence education - and with it in increasing the intelligence community's transparency and openness to the public - the study of intelligence outside the Romanian intelligence community remains a work in progress, partly because of minimal interest on the part of academia in intelligence studies, partly due to a rather tense relationship between the intelligence agencies and civil society (in particular scholars).

\section{Teaching and Learning Opportunities}

No Romanian university offers degrees in intelligence studies. There are several reasons why intelligence is not yet an established academic discipline in Romanian universities: the lingering stigma associated with Ceausescu's notorious Securitate; minimal interest in

\footnotetext{
${ }^{2}$ ANI curricula comprise the following: education in general intelligence (strategic intelligence, counterintelligence, analysis); education in intelligence culture (specific intelligence and counterintelligence terminology, history of domestic and foreign intelligence services, roles and missions, ethics, and democratic control); juridical education (teaching Romania's constitution and legislation pertaining to national security); and foreign languages. See Romanian Intelligence Service, 2019.

${ }^{3}$ Curricula include graduate and postgraduate education in law, public order, engineering, humanities. See Academia de Politie, 2019.
} 
a field that lacks the quantitative and qualitative information required for scientific research; distrust in the practical value of any purely theoretical research, or, conversely, aversion to participate in a research endeavour involving the government coupled with minimal understanding among outsiders of intelligence of the relevance of intelligence in strategic decision-making); limited academic expertise in intelligence; and lack of incentives to invest limited resources in intelligence research (Filip and Ştefureac 2011). Nevertheless, several master and doctoral programs at various civilian universities offer intelligence courses as part of international history, political science, international relations or security curricula. Besides teaching intelligence theory and intelligence history, some teach basic tradecraft, in particular analytic skills. Examples include the National School of Political and Administrative Studies, the Babes Bolyai University, the RomanianAmerican University, and the University of Bucharest (in particular the Faculty of Sociology M.A. course for Information Analysis, available for SRI's new analysts and intelligence outsiders) (Matei 2014b; Matei and Niţu 2012).

\section{Institutionalisation of Intelligence Studies}

The presence of scholars engaged in intelligence research in Romanian universities is a rather rare phenomenon. Several researchers - mostly from the National Institute for the Investigation of Communist Crimes, National Institute for the Investigation of Totalitarianism - have investigated the organization and activity of Romanian intelligence agencies during the pre-WWII time period, or the history of communism, in other words, the Securitate-era, by relying heavily on the archives housed in the CNSAS. ${ }^{4}$ The CNSAS itself also has published many intelligence dossiers from the Securitate-era, which exposed collaboration among the DSS and various politicians, academics, intellectuals, athletes, clergy members and journalists (Matei 2007a; Matei 2007b). By contrast, research conducted by scholars in Romanian universities on Romania's post-communist

\footnotetext{
${ }^{4}$ The SRI handed over most of its pre-WWII archives to the National Archives. The agency also transferred most of its communist regime archives to the National Council for the Studying of the Archives of the Securitate (CNSAS), established in the late 1990s. Exceptions have been made, however, on grounds of national security.
} 
intelligence agencies has been rather scarce. Since 2016, some research institutions have sought "to advance intelligence as an object of study that can be approached interdisciplinarily at the postgraduate (doctoral) level" to include such "topics as governance of intelligence agencies, forensics in intelligence collection and analysis, social and legal challenges associated to law enforcement and intelligence activities, citizens' perceptions on intelligence and security, reconciling open-source collection with fundamental rights of citizens, and rethinking national legislative frameworks for intelligence agencies have started to be investigated by an international team of young researchers in the ESSENTIAL project" (Chiru 2019). ${ }^{5}$

\section{Access to Information on Intelligence}

Outside researchers have relatively limited access to information about government intelligence structures, processes and practices-despite Freedom of Information Act (FOIA)-like legislation and other transparency and access laws and regulations-due to bureaucratic obstacles and unprofessional behavior on the part of government personnel. For example, even if the legal framework allows scholars - upon obtaining prior approval by the SRI director - to access non-classified information housed in the SRI archives, occasionally, the SRI personnel invokes "national security" to refuse access to intelligence (Matei 2007a). Likewise, archive employees reluctance to hand over documents has hindered scholars' access to information about intelligence activities (Matei 2007a). Researchers requesting declassification of documents contained in the SRI archiveswhich can only happen with the approval of a special committee — often face unnecessary challenges, mostly posed by heavy-SRI-personnel-dominated committee membership. Under these circumstances, Romanian intelligence researchers frequently rely on the SRI's official statements, news briefings, and interviews, media coverage of particular events, as well as CNSAS archives, to conduct their research. A few researchers - mostly from abroad (including the author of this section of the forum) - have been provided access to intelligence agencies' venues and successfully conducted interviews with Romanian

\footnotetext{
${ }^{5}$ ESSENTIAL (Evolving Security SciencE through Networked Technologies, Information policy And Law).
} 
intelligence officials. Other Romanian and foreign scholars also have contributed chapters to several volumes on intelligence edited or co-edited by intelligence professionals.

\section{Scientific Debate}

There is no professional association of intelligence researchers in Romania. Nevertheless, intelligence researchers routinely collaborate with intelligence agencies, in particular the SRI, to educate academia, members of the government, NGOs and media, as well as Romania's population on intelligence, by organizing seminars, conferences and summer schools. Since 2003, for example, the SRI's Center for Information on Security Culture has established "partnerships with universities, NGOs, and think tanks, functioning as an interactive platform and a source of specialized information in the form of studies, researches, and reports drafted by national and international organizations necessary for development of a security culture" (Filip and Ştefureac 2011). This partnership between practitioners and researchers resulted in debates and discussions of relevant security topics, such as combatting terrorism, arms proliferation, critical infrastructure protection, and border security. These discussion also helped build linkages between intelligence agencies and civil society (Filip and Ştefureac 2011). The European Institute for Risk, Security and Communication Management (EURISC), Casa NATO, and the Regional Center for Higher Studies on Bioterrorism Prevention - three Romanian research think tanks - have been constant collaborators with the SRI. Under the SRI's leadership, these think tanks conducted several anti-terrorism education campaigns titled "Terrorism...Near Us," which informed the population on possible effects of terrorism while highlighting the counter terrorism capabilities of the SRI's Anti Terror Brigade (Matei 2007b). Of relevance is the

leadership of former SRI's Director George Cristian Maior, who invested considerable time and resources in strengthening SRI's partnership with academia and civil society. Under Maior's directorship, the SRI established formal collaboration with several research and academic institutions, including: the National Institute for Research in Economics of the Romanian Academy (which granted the SRI access to Romania's greatest collections of books, research documents, engravings, and maps); the Romanian Academy's Political Science and International Relations Institute (which enabled the SRI to conduct joint 
research with the Academy); and the Faculties of Sociology from the University of Bucharest and, respectively, the Babes-Bolyai University of Cluj-Napoca (which allowed the SRI and these institutions to develop a joint assessment system of social networks). In Maior's view, these types of endeavors enabled the SRI "to work and interact with academic...to offer decisionmakers the intelligence needed to take the most accurate and timely decisions in the national security field" (Filip and Ştefureac 2011).

Nevertheless, the main event that has regularly brought together intelligence researchers and practitioners in Romania is the annual international conference titled Intelligence in the Knowledge Society hosted by the National Intelligence Academy. The conference's more than twenty iterations, according to Dumitru, "have provided opportunities to exchange ideas among practitioners, professors, and researchers having an interest in the field of security and intelligence, thereby contributing to the understanding and deepening of intelligence concepts and theories" (Dumitru 2014).

The ANI's National Research Institute conducts research for SRI and other security institutions, while reaching out to a national and international audience. It also publishes a bi-yearly intelligence and international relations journal entitled Romanian Journal of Intelligence Studies (Matei 2014b). The journal aims, in Dumitru's view, "to facilitate a common understanding of the intelligence field at the national level...the journal is a consistent mix of theoretical and empirical studies on intelligence, both descriptive and prescriptive" (Dumitru 2014). The military intelligence agency —DGIA — also publishes a specialized intelligence journal called Infosfera, which is available on the website of the Ministry of Defense. Although its target audience is military intelligence professionals, it also helps to inform a wider public who is interested in learning about intelligence, security, and defense (Matei 2014b).

\section{Relationship Between Researchers and Practitioners}

Since 1989, Romania's practitioners have slowly developed a connection with outside intelligence researchers. For example, the Gradistea and Bran training centers collaborate 
with education and training institutions outside of the intelligence community. ANI sometimes selects and enrolls recruits from civilian universities in its postgraduate programs (Timofte 2003). In addition, ANI sometimes provides tuition-based undergraduate and graduate education to personnel outside intelligence or national security institutions, such as public authorities and institutions, NGOs, and Romanian citizens permanently residing in Romania. ANI also trains foreign students who receive scholarships from the Romanian government (Cristescu 2002, 140-142). In addition, retired intelligence officers either work in the private sector or help set up NGOs and think tanks - such as the New Strategy Center - that support the Romanian intelligence agencies with specific estimates and analyses. Active duty intelligence officers also teach and collaborate with faculty and students at various civilian universities, including the Law, Political Science and Sociology Faculties of the University of Bucharest and the Economic Studies Academy in Bucharest. These intelligence professionals also participate in international conferences organized by civilian universities, including the National School for Political and Administrative Studies, the Institute for Political Studies and Military History of the Romanian Ministry of Defense (Filip and Ştefureac 2011). Conversely, guest faculty from civilian universities and from western countries are teaching on topics such as journalism, communications and letters in ANI (Timofte 2003).

Despite Romania's significant progress since the 1989 democratic transition in developing a new intelligence education system for its intelligence community, the study of intelligence outside Romanian intelligence agencies themselves has remained sporadic and undeveloped, due to limited academic interest in intelligence studies and often strained relationships between intelligence professionals and academics. In other words, Romania's universities have yet to recognize and intelligence as a true academic discipline and hence focus on producing subject matter experts that are utilized by intelligence agencies. Indeed, as Filip and Stefureac observe, "Romanian universities ... remain a pool of potential recruits and providers of expertise, but only on specific topics related to world politics, economics, political science, and a multitude of other disciplines-except intelligence itself' (Filip and Ştefureac 2011). 


\section{SPAIN (Antonio Díaz Fernández)}

The emergence of intelligence studies in Spain followed the democratisation of its intelligence services in the post-Francoist era. At the dawn of the twenty-first century, the Spanish government established the National Intelligence Centre (Centro Natcional de Inteligencia or CNI), merging both foreign and domestic intelligence capabilities in a single organisation. The first civilian chief of Spanish intelligence, ambassador Jorge Dezcallar de Mazarredo, played an important role in promoting greater collaboration between the services, academics and Universities to further public knowledge about the role of intelligence in Spain. This effort has become particularly visible through the introduction and multiplication of intelligence studies programs at Spanish universities. This development has fostered intelligence research and teaching opportunities but also raises questions about the quality and legitimacy some of these programs.

\section{Access to Information on Intelligence}

Spanish researchers have limited access to information on government intelligence practices, which in turn inhibits the development of intelligence studies in Spain. Access is regulated by a pre-constitutional norm - a law on Official Secrets which was passed on 5 April 1968 and amended in 1978. As a result, it is difficult to gain access to government intelligence archives and, in many cases, it is simply impossible to retrieve materials at all (Malalana-Ureña and Moreno-Pérez 2017). Occasionally, researchers have even obtained Spanish documents from foreign archives while simultaneously being denied access to those same documents in Spain.

In 2013, a group of 300 historians complained to the Government and various parliamentary political groups about the prohibition on access to the archives of the Ministry of Foreign Affairs, which was put into place by an agreement of the Council of Ministers of 15 October 2010. This agreement extended the classification of all documents related to 17 policy areas, including access to information on all Spanish diplomatic relations. In 2011, the Minister of Defense, Carme Chacón, ordered the analysis and 
cataloguing of all archives covering the period between 1936 and 1968 with an eye towards declassification. A change in government, however, halted the process. In September 2018, the government announced that scholars would be granted access to the documentation held at the Military Archive of Avila. This was a step forward, albeit a limited one - the grant of access did not extend to the 18 other archives maintained by the Ministry of Defense. There also is no routine release of administrative information about Spain's intelligence agencies. Unlike other government departments, neither the Parliamentary supervisory committee nor the intelligence service itself publishes an annual report.

The main method to access information about Spain's intelligence services has been to rely on oral sources. Former intelligence officers and politicians have been increasingly willing to share insights, which has helped to make the recent history of the intelligence services a bit more transparent and comprehensible. In addition, more than a few former officials have made documents available to researchers (Díaz-Fernández 2005, 35-46). Relying on former intelligence officials as a source of information, however, has obvious limits, not the least of which is the fact that their experiences and their memories go back no further than the decade of the 1960s. The generation of intelligence professionals who can provide first hand accounts of earlier times has largely passed from the scene, creating an information vacuum for researchers interested in the first decades of the Cold War.

In 2002, an intelligence culture unit, the Centro Nacional de Inteligencia (CNI), was set up in the intelligence service. Its objective is to facilitate communication with the public and to foster awareness of intelligence matters within society, including the research community (Galvache Valero 2005). Inaugurated under the auspices of the first civilian director of the CNI, ambassador Jorge Dezcallar, this unit has played an important role in fostering interest in intelligence affairs among academics and other social, political, and economic actors in the country. The intelligence culture unit has encouraged the formation of an academic community of intelligence scholars in which its proposals and initiatives have wielded influence. Nevertheless, the services have not achieved the degree of openness necessary to respond to demands for information from researchers due, in part, 
to internal resistance from those inside intelligence agencies who would prefer to keep the scholarly community at bay.

\section{Institutionalization of Intelligence Studies}

The community of Spanish intelligence scholars is small. Around 20 social scientists have an interest in intelligence studies and no more tan 12 of them have made it their main research interest. In addition, a growing community of scholars has undertaken intelligence related research in a tangential manner. Moyano, Gaete and Rivas (2014) find that these scholars form disconnected groups rather than a fluid community.

A handful of universities have signed collaboration agreements with the intelligence service. These agreements are a good indicator of where intelligence studies researchers work. Following the pioneering initiatives of the University Rey Juan Carlos (Madrid), which established the chair in Intelligence Services and Democratic Systems, and the University Carlos III (Madrid), which established the Juan Velázquez de Velasco Institute, the Universities of Barcelona, Valencia, Malaga, Granada, Cadiz and the Barcelona Institute of International Studies (IBEI) also signed agreements with the CNI. These agreements identify the activities that the partners will perform during the year, such as seminars, publications, and conferences, as well as their respective contribution to these activities. Beside these agreements, researchers working at centers linked to the Ministry of Defense - such as the Centro Superior de Estudios de la Defensa [CESEDEN] and the Instituto Español de Estudios Estratégicos [IEEE] - have also developed intelligence studies projects. Nevertheless, important think tanks, such as the Real Instituto Elcano and the Fundación Alternativas devote few resources to the study of intelligence affairs.

\section{Scientific Debate}

In Spain, initial interest in the study of intelligence emerged from journalists, not historians (Blanco and Díaz 2015, 11). Today, the most consistent scientific forum to debate intelligence affairs is the Asociación Española de Ciencia Política (AECPA), in which a 
standing group on "Intelligence and Strategic Analysis" was launched in 2017. The objectives of this standing group are: (1) to promote research on Intelligence and Strategic Analysis; (2) to establish academic and research networks among intelligence professionals and political scientists; and, (3) to consolidate and codify the academic study of intelligence in Spain. This group, which meets on a biannual basis at the AECPA conference partially took over the leadership of the four international conferences on intelligence that were held in Madrid (2008 and 2010), Barcelona (2012), and Cadiz (2014) and were supported by the network of Universities involved in the intelligence culture project inaugurated by the CNI. The conferences organized by the Grupo de Estudios sobre Seguridad Internacional (GESI) of the University of Granada provides another meeting place for intelligence researchers. In addition to these formalized meetings, intelligence scholars' contribution to graduate courses, edited volumes and seminars helps to sustain useful exchanges among groups of researchers.

While these fora bring together social scientists and International Relations scholars, they have not included historians and engineers. Experts working on cybersecurity and intelligence, and economic and competitive intelligence have their own networks, such as the Spanish chapter of Strategic and Competitive Intelligence Professionals (SCIP). An analysis of doctoral theses on intelligence in Spain reveals the existence of two large clusters of unconnected groups of intelligence researchers (Moyano, Gaete and Rivas 2014, 224-225).

The diffuse character of Intelligence Studies in Spain is one of the main concerns that drove the establishment of an intelligence studies journal in 2006: Inteligencia y Seguridad. Revista de Análisis y Prospectiva. Although the journal was sponsored by the CNI, it enjoyed scientific independence. This academic journal has had an important role in bringing together the nascent Spanish and Latin-American research communities. Edited by the chair of Intelligence Services and Democratic Systems of the University Rey Juan Carlos and published by Plaza y Valdés, between 2006 and 2015, this journal fostered scholarly interest on intelligence matters. After 17 issues, the editors reached an agreement with the Taylor and Francis publishing house in 2015, to continue as an English language 
journal, with abstracts continuing to appear in Spanish. Following this change, the journal was renamed as The International Journal of Intelligence, Security, and Public Affairs.

The evolution of Inteligencia y Seguridad into an English-language publication, reflects the limited growth of intelligence studies in Spain and in the Spanish-speaking world. The Spanish version of the journal struggled to make an impact on the broader field of Intelligence Studies, over-relied on the same authors researching similar topics, and reflected a general lack of resources needed to inform and contribute to broader intellectual debates in the international community of intelligence researchers. No longer publishing fully in Spanish reduced the impact of Spanish and Latin American researchers and cases fielding the Spanish speaking world, but this change helped broaden the journal reach a wider academic audience in the "Anglosphere." In 2018, the journal was incorporated into SCOPUS, further increasing its impact and broadening its reach.

A book series entitled Inteligencia y Seguridad was launched by the publisher Tirant Lo Blanch, one of most distinguished publishers in Spain, with the objective of disseminating research on intelligence matters. First published in 2012, the series is edited by professor González Cussac and counts 15 monographs to date. The fact that this prestigious publisher launched this series on intelligence suggests that intelligence studies research is now on the rise. In addition to this series, two edited volumes on intelligence have brought together over eighty experts from various disciplines including criminology, political science, journalism, history, and computing, and ex-members of the intelligence services (DíazFernández 2013; Díaz-Fernández 2016). These two volumes have helped establish a theoretical corpus and common vocabulary on intelligence for Spain and Latin America, while offering a recent research on intelligence organizations and practices.

These initiatives and publications highlight the broad research trends in intelligence studies in Spain. Today, research largely focuses on (1) economic and competitive intelligence, (2) the legal dimensions of intelligence, (3) history, archiving, and information security, and (4) intelligence and terrorism (radicalization, international cooperation, case studies). Despite a number of positive developments, however, the ability of Spanish researchers to 
generate a scientific debate that contributes to broader international currents in intelligence research remains limited.

\section{Teaching and Learning Opportunities}

The first university course on intelligence was delivered at the General Gutiérrez Mellado University Institute in Madrid in 2003. Since then, courses of varying quality have proliferated. Sometimes, a lack of available materials meant that many courses were translations of Anglophone courses and textbooks. An expansive, albeit not a completely misleading, definition of "intelligence" was used to attract students to short courses of questionable scientific quality, while courses that were not focused on intelligence were marketed as intelligence courses to increase their appeal to potential students.

A study by Díaz and Barco (2015) compiled a list of 12 Master's programs and 55 courses on intelligence that are offered by universities or other schoolhouses in Spain. Some of these teaching opportunities are provided at little-known educational centers with no academic track record, which poses questions regarding their quality and legitimacy. Díaz and Barco's study points out issues with the quality of a number of courses offered at these institutions, including the lack of engagement with theoretical content, which is a defining feature of scientific research and teaching. They also found that sometimes these course lacked conceptual rigor and simply presented basic concepts such as the intelligence cycle without approaching them critically. Recent data gathered in April 2019 shows that only nine MA programs now exist, a reduction that probably reflects high fees, a shortage of teaching staff, and limited opportunities for graduates to gain employment.

To overcome difficulties in gaining employment upon graduation, the Master's in Intelligence Analysis offered at the Universidad Rey Juan Carlos since 2009 has established a number of partnerships to provide internship opportunities for its students. This program focuses on teaching students how to conduct analysis and is probably the best program for students seeking a career in intelligence. By contrast, other intelligence studies programs in Spain find it difficult to place their students inside intelligence 
agencies. This issue is growing in importance at a time when alumni associations are beginning to recognize the role of economic and business intelligence.

\section{Relationship Between Researchers and Practitioners}

Former members of the Spanish intelligence services have demonstrated a willingness to come forward and publicly explain the work of the intelligence services. Although as individuals they have long shown a willingness to discuss intelligence matters with researchers, their collaboration became more visible since 2012. This shift in relations between intelligence practitioners and researchers was prompted by the CNI's new policy of openness, which was most visible in the establishment of an Asociación de Ex-Miembros del Servicio de Inteligencia Español [ASEMI, Association of Ex-Members of the Spanish Intelligence Service]. This official association now counts 110 members and replaces an earlier group that brought together abour 65 members. This association has no structural or functional relation with CNI. Its objective is to make the intelligence culture known, without engaging in partisan debates, to better inform society about the need for and roles played by the intelligence services.

ASEMI's participation in conferences, summer courses, and television programs has been notable. Key figures in ASEMI have held high-level positions in the intelligence community and some of them also have a doctoral degree, which can explain their ability and willingness to engage the academic community. This group of retired professionals increasingly find themselves employed as instructors in Master's courses, and other courses and seminars. They are a growing presence in educational programs as speakers, tutors, and evaluators of essays and doctoral theses. Some of them have made important contributions to the public and academic debates on intelligence in Spain. Nevertheless, the participation of intelligence professionals in scholarly research and debate about intelligence remains limited. Former military intelligence professionals in particular, and to a lesser extent former members of law enforcement agencies such as the National Police and Civil Guard, have tended to shy away from involvement in academia. 
The Centro de Desarrollo Tecnológico e Industrial (CDTI) [Centre for Technological and Industrial Development] of the Ministry of Economy has provided another platform for academics, the business world, and law enforcement agencies to meet and exchange ideas. Unlike twenty years ago, when there was no door to knock upon and no telephone number to call, all the security forces and the Ministry of the Interior have established contact points - principally to support participation in projects sponsored by European funding bodies. Nevertheless, these points of contact can provide a way to reach out to other professionals with expertise on a diverse set of issues. The divide between practitioners and academics, however, can sometimes complicate close collaboration. For instance, the topics that are of greatest interest to these agencies, mostly law enforcement and cyber security, do not always align particularly well with the more theoretical interests of many academics.

In summary, Spanish intelligence studies has grown since 2002, the point when scholars and practitioners worked together to establish the core elements necessary to form a scientific community: publications, periodic fora, teaching and training opportunities. Nevertheless, the field went through a crisis spurred by its growth after 2012. The quantity of courses taught was not supported by production of sufficient and relevant scientific material. The lack of original research based on primary sources and the inability to access key documentation and data limited the scholarly community's theoretical contributions to broader academic debates. Yet, research on Spain's distinct experience in intelligence - a country that was not directly involved in the Cold War and continues to recover from its Francoist past - has much to offer to broader debates in the fields of Intelligence Studies and International Relations.

\section{UNITED KINGDOM (Damien Van Puyvelde)}

The United Kingdom has a well-estbalished intelligence culture supported by a relatively dense network of intelligence scholars based at a dozen higher education institutions. The "British school" of intelligence studies has traditionally been associated with the historical method, following the work of former practitioners turned official historians such as Harry Hinsley and M.R.D. Foot. The government has fostered the emergence of scholarship on 
intelligence by opening some of its archives and commissioning official and authorised histories of the intelligene services. In the last decade, a number of scholars have developed a more applied and professionalising approach to the study and teaching of intelligence and national security. This can be related to broader trends in British higher education, emphasizing the need to develop professionalising Master's programs and generate research "impact" (Moran and Browning 2018).

\section{Access to Information on Intelligence}

Historical and archival research has dominated the British approach to intelligence studies. In an era marked by the opacity imposed by the Official Secrets Act, subsequent British governments have decided to endorse and commission official histories of its secret institutions. The first such history was M.R.D. Foot's SOE in France (1966), which describes the exploits of the Special Operations Executive during the Second World War. Her Majesty's Government later provided access to its intelligence archives to a team of researchers led by Bletchley park cryptanalyst and historian Harry Hinsley. Hinsley and his colleagues would use this access to research the Official History of British Intelligence in the Second World War from 1971 onwards. The first volume was published in 1979, and four additional volumes followed in the next decade (Hinsley et al. 1979, 1981, 1984, 1988, 1990). In the 1970s, former practitioners divulged two of the most sensitive secrets of the Second World War: British SIGINT capabilities and deception efforts (Masterman 1972; Winterbotham 1974). These revelations, and those of investigative journalists like Chapman Pincher, triggered the interest of outside researchers at a time when the government remained very secretive about its intelligence services (Moran 2012, 95135). Christopher Andrew published a seminal history of the British Secret Services (Andrew 1985), using parallel research - going through the records of multiple government departments - to find files that had been left by the security reviewers. The Cambridge historian would later co-author a series of key books on the history of Soviet intelligence with defectors Vasili Mitrokhin and Oleg Gordievsky, and the relationship between US Presidents and their intelligence community (Andrew 1990, 1995, 1999). 
At the end of the Cold War, Parliament officially recognised the existence of the Secret Services (MI5), the Secret Intelligence Service (SIS or MI6), and the Government Communications Headquarters (GCHQ). The Secret Intelligence Services Act further established a parliamentary intelligence oversight committee, which has published an annual report since 1995 (Parliament of the United Kingdom 1989 and 1994). Government releases, specifically in the records of the Cabinet Office, the Security Service, and the Foreign Office, have allowed outside researchers to continue investigating the history of British intelligence. Nevertheless, many files, specifically those of SIS, remain inaccessible to outside researchers who are forced to use parallel research, visit foreign archives, and consult private papers to unearth evidence about British intelligence practices. The British Cabinet Office organises periodic consultations with intelligence researchers to discuss declassification issues, which help to maintain a dialogue between government and the research community.

The study of intelligence in the United Kingdom continues to be defined by the production of official and authorised histories, with volumes on the MI5, MI6, and the Joint Intelligence Committee (JIC) released in the last decade (Andrew 2009; Jefferey 2010; Goodman 2014). Military historian John Ferris is currently working on an official history of GCHQ. Beside archives and government records, journalists writing about intelligence and researchers have relied on interviews with serving and former officers to write about secret intelligence (see for example Urban 1996; Aldrich 2011; Corera 2012). A handful of former senior intelligence practitioners such as former GCHQ officer and Secretary of the Joint Intelligence Committee Michael Herman (1996) and former Director of GCHQ David Omand (2010), have written influential monographs at the crossroads between intelligence theory and practice. Additionally, former MI5 Director Stella Rimington (2002) published her memoir, and Eliza Manningham-Buller (2012) wrote a short and informative essay on security and counter-terrorism based on a series of public lectures. In sum, intelligence researchers have benefited from limited government transparency.

\section{Institutionalization of Intelligence Studies}


The study of intelligence is longstanding in the British academic landscape. The relative flexibility of UK higher education, and its openness to interdisciplinary approaches, has provided a fertile ground for intelligence studies to flourish at the crossroads between humanities and the social sciences. Intelligence researchers can be found in politics, international relations, criminology and history departments in well over a dozen Universities. Few of these researchers have a background in intelligence.

A handful of universities have established centres to structure their research efforts. Brunel University created the Brunel Centre for Intelligence and Security Studies (BCISS) in November 2003 to promote and develop social science and policy-oriented approaches to intelligence. Aberystwyth University established a Centre for Intelligence and International Security Studies (CIISS) in 2004. The University of Buckingham established its own Centre for Security and Intelligence Studies (BUCSIS) a few years later. Over a dozen universities offer intelligence related courses, many of which are based on the latest research in the field.

British researchers have played an essential role in the structuring of intelligence studies as an academic field of enquiry. In 1986, Christopher Andrew helped establish the first academic journal on intelligence, Intelligence and National Security, with Michael Handel at the US Army War College (Phythian 2017). British publisher Frank Cass, later acquired by Routledge, provided an early platform to publish monographs and edited volumes on intelligence. Two major book series - Studies in Intelligence (Routledge), and Intelligence, Surveillance and Secret Warfare (Edinburgh University) - have now published dozens of research monographs on intelligence affairs.

Intelligence scholars based in Britain form a closely-knit community supported by periodic meetings organised by various institutions such as the Cambridge Intelligence Seminars, the Oxford Intelligence Group, the Study Group on Intelligence (currently led by Professor Michael Goodman, King's College London), and the biennial Gregynog Conference organised by the Centre for Intelligence and International Security at Aberystwyth University. The Universities of Aberystwyth, Brunel, Cambridge, King's College London, 
Oxford, and Warwick, to name a few, have produced a steady flow of PhD candidates working on intelligence affairs in the last two decades. Early career researchers tend to organise ad hoc workshops and events that add to the more periodic and well-established events. In addition, King's College London has set up an Intelligence and Security email digest that acts as a central channel of communication on Intelligence Studies events in the UK and beyond.

\section{Scientific Debate}

Intelligence researchers in the UK have been influenced by the importance of the historical method in the development of the field, and tend to look at the past to identify cases, trends and broader developments in the practice of intelligence. Common research themes have been shaped by the availability of government records and include the role of intelligence in war, intelligence and the British Empire and intelligence and decolonization, to name a few (see for example Cormac 2013). A handful of social scientists have written about the British intelligence bureaucracy and the evolution of its oversight mechanisms (see for example Davies 2005; Phythian and Gill 2006).

More applied research on intelligence sources and methods remains relatively limited in the UK. Even publications on intelligence analysis tend to be more academic than applied in their nature (see for example Richards 2010). Nevertheless, the establishment of a Centre for Research and Evidence on Security threats (CREST) at Lancaster University, thanks to a grant from the British government, suggests that new and more applied approaches to intelligence and security are becoming more important in a higher education context due in part to growing expectations regarding the "impact" generated by academic research. CREST has provided support to social and behavioural scientists working on topics of interest to intelligence and security agencies including the elicitation of information, protective security and risk assessment, and radicalisation processes. While the researcher leading these projects might not define themselves as "intelligence scholars" primarily, their findings are likely to affect the ways in which intelligence is studies in the UK. 


\section{Teaching and Learning Opportunities}

UK universities have a relatively long tradition of offering academically oriented courses on intelligence. In the late 1980s, the University of Edinburgh offered a Master's in History of American Security and Intelligence. Historians at the University of Salford followed suit and developed of a Master's programme on intelligence (Phythian 2018). The Department of International Politics at Aberystwyth University started offering an undergraduate course on Intelligence and National Security in 1991, and a Master's course in 1993, and appointed a tenure-track Lecturer in Intelligence Studies in 1996 before offering a Bachelor of Science in International Politics and Intelligence Studies, and from 2003 onwards, an MA in Intelligence.

Intelligence studies emerged as a branch of the history of international relations and the study of international politics. Unsurprisingly, the UK tradition of intelligence teaching focuses on intelligence education. Intelligence is taught in the context of its ability to inform and impact international history and international relations. Courses on intelligence analysis tradecraft have emerged in the last decade at the Master's level and have become increasingly successful. Table 2 provides a snapshot of intelligence courses and programmes offered at UK universities in 2019. The sample focuses on courses in the humanities and social sciences, and excludes other disciplines such as business, information studies, and computer science.

\section{INSTITUTION DEGREE - COURSE}

\begin{tabular}{|l|l|}
\hline Aberystwyth & BA in Strategy, Intelligence and Security \\
University & - War, Strategy and Intelligence \\
& - Strategy, Intelligence and Security in International Politics \\
& - Spies at War \\
& MA in Intelligence and International Security / International \\
& $\begin{array}{l}\text { Relations / etc. } \\
\text { - Intelligence, Security and International Relations in the 20th } \\
\text { Century }\end{array}$
\end{tabular}




\begin{tabular}{|c|c|}
\hline $\begin{array}{l}\text { Bishop } \\
\text { Grosseteste } \\
\text { University }\end{array}$ & $\begin{array}{l}\text { BA in History } \\
\text { - The Secret State: A history of espionage } \\
\text { - The Secret War: Intelligence during the Second World War }\end{array}$ \\
\hline $\begin{array}{l}\text { Brunel } \\
\text { University }\end{array}$ & $\begin{array}{l}\text { BSc in International Politics / Politics / Politics and History } \\
\text { - National Security Intelligence } \\
\text { MA in Intelligence and Security Studies (face-to-face and } \\
\text { distance learning) } \\
\text { - Intelligence Concepts, Issues and Institutions } \\
\text { - Intelligence and Security Studies Dissertation } \\
\text { - Intelligence History: Failure and Success } \\
\text { - Contemporary Threats and Analytical Methodology } \\
\text { - Counterintelligence and Security } \\
\text { - Intelligence Analysis Foundations, Methods and Applications }\end{array}$ \\
\hline $\begin{array}{l}\text { Buckingham } \\
\text { University }\end{array}$ & $\begin{array}{l}\text { BA in Security, Intelligence and Cyber } \\
\text { - Foundations of Global Security and Intelligence } \\
\text { - Key Developments in Security and Intelligence History } \\
\text { - Political Psychology and Intelligence analysis } \\
\text { - Security, Intelligence and Policy-Making } \\
\text { MA in Security and Intelligence Studies OR in Security, } \\
\text { Intelligence and Diplomacy } \\
\text { - Intelligence History, Tradecraft and Machinery } \\
\text { - Case Studies in Intelligence Success and Failure } \\
\text { - Analytical Simulation Exercise } \\
\text { Postgraduate Certificate or Diploma in Law Enforcement, } \\
\text { Security and Intelligence (face-to-face and distance learning) } \\
\text { - Law Enforcement Intelligence Practice and Policy } \\
\text { - Intelligence and International Security since } 1939\end{array}$ \\
\hline $\begin{array}{l}\text { Coventry } \\
\text { University }\end{array}$ & $\begin{array}{l}\text { BA in History } \\
\text { - British intelligence history from 1789-1989 }\end{array}$ \\
\hline $\begin{array}{l}\text { University of } \\
\text { Derby }\end{array}$ & $\begin{array}{l}\text { MSc/Postgraduate Certificate or Diploma in Intelligence, } \\
\text { Security and Disaster Management }\end{array}$ \\
\hline
\end{tabular}




\begin{tabular}{|c|c|}
\hline & - Contemporary Issues in Intelligence and Security \\
\hline $\begin{array}{l}\text { University of } \\
\text { Glasgow }\end{array}$ & $\begin{array}{l}\text { MA in History } \\
\text { - Covert action: the secret pursuit of foreign policy from the } \\
\text { Second World War to today } \\
\text { - Evolution of the US Intelligence Community } \\
\text { International Master in Intelligence, Strategy and Security } \\
\text { Studies } \\
\text { - Intelligence Analysis and Policy-Making } \\
\text { MA in Global Security } \\
\text { - Intelligence in an Age of Terror }\end{array}$ \\
\hline $\begin{array}{l}\text { King's College } \\
\text { London }\end{array}$ & $\begin{array}{l}\text { BA in International Relations / War Studies / History and } \\
\text { International Relations / etc. } \\
\text { - Intelligence and War } \\
\text { MA in Intelligence and International Security / International } \\
\text { Relations / National Security Studies / etc. } \\
\text { - Intelligence in Peace and War } \\
\text { - Diplomacy, Intelligence and Armaments Competition } \\
\text { - Intelligence Studies [Cabinet Office Only] } \\
\text { - Armchair Intelligence - Open sources and online } \\
\quad \text { investigations } \\
\text { - Past and Present of British Intelligence }\end{array}$ \\
\hline $\begin{array}{l}\text { Leicester } \\
\text { University }\end{array}$ & $\begin{array}{l}\text { MA in Intelligence and Security (distance learning) } \\
\text { - Intelligence : Key Concepts and Debates } \\
\text { - Intelligence Techniques and Tradecraft } \\
\text { - Intelligence Failure } \\
\text { - Intelligence Ethics }\end{array}$ \\
\hline $\begin{array}{l}\text { Liverpool John } \\
\text { Moores } \\
\text { University }\end{array}$ & $\begin{array}{l}\text { MSc Intelligence and Security Studies (distance learning) } \\
\text { - Intelligence Analysis } \\
\text { - History of intelligence: Successes and Failures }\end{array}$ \\
\hline
\end{tabular}




\begin{tabular}{|c|c|}
\hline $\begin{array}{l}\text { University of } \\
\text { Nottingham }\end{array}$ & $\begin{array}{l}\text { MA in International Security and Terrorism } \\
\text { - Secret Intelligence and International Security }\end{array}$ \\
\hline $\begin{array}{l}\text { Salford } \\
\text { University }\end{array}$ & $\begin{array}{l}\text { BSc in Politics } \\
\text { - Intelligence, Security and Politics in Britain, 1909-1994 } \\
\text { MA/PgDip in Intelligence and Security Studies (face to face, } \\
\text { distance learning closed to practitioners) } \\
\text { - Contemporary Security, Intelligence and Terrorism Studies } \\
\text { - } \quad \text { Intelligence and Conflict } \\
\text { - } \quad \text { Issues in Intelligence } \\
\text { - } \quad \text { The Secret State }\end{array}$ \\
\hline $\begin{array}{l}\text { Staffordshire } \\
\text { University }\end{array}$ & $\begin{array}{l}\text { BSc Intelligence and Security (for Ministry of Defence employees } \\
\text { only) } \\
\text { - IT support for Intelligence } \\
\text { - Digital Forensics for Intelligence }\end{array}$ \\
\hline $\begin{array}{l}\text { Warwick } \\
\text { University }\end{array}$ & $\begin{array}{l}\text { BA in Politics and International Studies / etc. } \\
\text { - Vigilant State: The Politics of Intelligence } \\
\text { MA in International Relations/Security } \\
\text { - The CIA and Covert Action } \\
\text { - Secrecy and Spies: British Intelligence in the Modern World }\end{array}$ \\
\hline
\end{tabular}

Table 2. Intelligence Studies Degrees and Courses at UK Universities, 2019

\section{Relationship Between Researchers and Practitioners}

The relationship between intelligence researchers and practitioners is cordial and informal, for the most part. A small number of former practitioners attend some of the periodic academic meetings organised. A handful of practitioners such as David Omand have been hired as professors and teach more regularly to university students. The intelligence services occasionally invite select scholars to deliver lectures to present their latest research. Former directors and service historians occasionally deliver lectures on university campuses. Nevertheless, there are no government-run programs like the US Intelligence Community Center for Academic Excellence, officers-in-residence or scholars-in- 
residence. Thus far, the British government seems to have favoured a relatively informal and unstructured approach in its relationship to the community of intelligence researchers based in the UK. This relationship is much more formalised when well-established researchers are granted privileged access to write authorised or official histories. Overall, intelligence researchers - including the authors or authorised and official histories - have focused their efforts on the academic study of intelligence.

\section{UNITED STATES (James J. Wirtz)}

Historical legacies and the politics of the day inevitably shape the study of intelligence. In the United States, collaboration between intelligence and academe was high during World War II, the early Cold War and during the so-called Global War on Terrorism. By contrast, as U.S. involvement in the Vietnam War increased, critical intelligence studies became a cottage industry (Marchetti and Marks 1974; Diamond 1992). The presence of CIA recruiters on college campuses became a lighting rod for all types of protest; scholars engaged in intelligence contract studies could also find themselves the target of vilification (Campbell 1986). Rightly or wrongly, intelligence agencies are sometimes depicted as enemies of democracy at home and enemies of the poor and exploited overseas - something worthy only of condemnation not serious scholarly consideration. Nevertheless, the existence of a national community of intelligence scholars probably implies that some amount of constructive communication occurs across the divide that separates intelligence agencies from academe. With these qualifications in mind, scholars in the United States often enjoy constructive working relationships with intelligence professionals, especially after both sides build trust during nearly continuous engagement in a variety of activities and venues.

\section{Access to Information on Intelligence}

Although it is impossible to judge how much information remains hidden behind classification barriers, those interested in the US intelligence community can actually be inundated with data about intelligence. Intelligence agencies routinely release archival 
material - policies, procedures and organizational structures are often a matter of public record. Excerpts of intelligence reports are often deliberately released or leaked by administration officials, retired intelligence professionals often chronicle important developments in their memoirs (Compton 2013) and FOIA requests can yield vast amounts of material. ${ }^{6}$ Admittedly, intelligence professionals would prefer to control tightly information releases, focusing on matters of mostly historical interest. Nevertheless, information floodgates open in the aftermath of intelligence failures or controversies. The Church Committee investigations in the 1970s (Johnson 2015), the Team B Experiment (Rovner 2011, 113-136), the 9/11 attacks (National Commission on Terrorist Attacks Upon the United States 2004), or the 2003 Iraq National Intelligence Estimate (Jervis 2010; Wirtz 2014) all yielded staggering amounts of information not only about the contents of intelligence estimates per se, but also how those intelligence estimates were produced.

Scholars also benefit from the fact that intelligence agencies in the United States retain their own historians not only to write official history, but also to organize and release archival materials in ways that are useful to "outside" historians (Dujmovic 2011). These agency historians disseminate information not based on policy mandates or professional courtesy alone, but out of a recognized need to advance our collective understanding of past events to help improve the intelligence process itself. Although the thought might be disconcerting in other national settings, intelligence scholars and intelligence professionals sometimes see themselves as addressing slightly different facets of the same issues or problems.

\section{Institutionalization of Intelligence Studies}

U.S. universities that offer graduate or professional programs related to international relations, security studies, or comparative government likely have at least one member of their faculty who has written about intelligence or who would self-identify as contributing

\footnotetext{
${ }^{6}$ The Central Intelligence Agency website supplies instructions and templates to facilitate requests for information using Freedom of information Act authorities (Central Intelligence Agency 2019).
} 
to the field of intelligence studies. These faculty are embedded in more "mainstream" political science or history programs and seem to branch out into intelligence studies after encountering issues of theoretical or empirical importance in their normal pursuits. In the aftermath of $9 / 11$, criminal justice departments, burgeoning homeland security programs, and public policy curricula often utilize faculty with research interests related to intelligence production, intra-agency intelligence collaboration, or intelligence oversight and privacy. The controversy surrounding the Second Gulf War, especially the debate about the accuracy of the 2002 National Intelligence Estimate on Iraq (National Foreign Intelligence Board 2002), also highlighted the role and power of intelligence estimates in policy and policy debates, drawing fresh voices from new disciplines to intelligence studies.

Today, issues of privacy raised by the emergence of "Big Data," the Internet of Things and the general digitization of everyday life are also drawing scholars from a variety of fields closer to topics traditionally addressed by intelligence studies. The field of intelligence studies also is changing to accommodate these new developments. While the field still focuses on the process of intelligence production, the impediments that bedevil analysts, and the governance and oversight of intelligence organizations in democracies (Gill, Marrin, and Pythian 2009), scholars are increasingly exploring how the issues of secrecy, privacy, artificial intelligence and the data deluge itself are shaping intelligence organizations, societies and the nexus among civil society, government and intelligence organizations (Wirtz 2019). In other words, intelligence studies in the United States might be poised to diffuse into the broader study of the impact of information technologies on society writ large.

\section{Scientific Debate}

As we noted in the introduction to this forum, while important theoretical and historical work on intelligence was not unknown in the United States before the 1980s, witness the seminal Pearl Harbor: Warning and Decision (Wohlstetter 1962), an expanding intelligence studies had become quite vibrant by the turn of the century. The Intelligence 
Studies Section of the International Studies Association and the Association of former Intelligence Officers, for instance, provide venues to present research and to network with like-minded scholars. The leading journals in the field benefited from editors who worked diligently to advance the state of the art, creating an air of competition between the two publications that has been inherited by a new generation of scholars that has recently taken over the helm. Publications dealing with intelligence also are becoming more commonplace in mainstream journals as young scholars work to raise their professional profiles. Just about all of the major university presses in the United States continue to publish noteworthy works on intelligence, while a few have even developed their own specialized series to tap interest in the topic and to draw younger scholars to their press.

Because Americans benefit from a large active community, enjoy plenty of venues and publications to distribute their work, and have a plethora of relevant materials, their selection of case studies, theoretical preoccupations and policy concerns tend to dominate the field, much to the chagrin of scholars living in other countries. As one young voice recently noted, "the temple of intelligence studies contains highly detailed reliefs about the same stories, while so much more could be carved into the edifice" (Lasoen 2018). Indeed, there are plenty of details about the workings of US and British intelligence during World War II, the Cuban Missile Crisis and a variety of Cold War incidents, the 9/11 attacks, intelligence leading up to the Second Gulf War and the hunt for Osama Bin Laden - issues that tap American and British archives and reflect US political and strategic concerns. This focus on the "Angloshpere," to use a term made popular by British colleagues, is changing, albeit slowly. Nevertheless, young scholars, regardless of their point of national origin, would do well to familiarize themselves with the Pearl Harbor story, since so much of the field takes this case as a reference point. American and, to a slightly lesser extent, British history still serves as the empirical bedrock of intelligence studies.

\section{Teaching and Learning Opportunities}

Intelligence studies in the United States can be found in both traditional programs at major research universities and in programs offering professional degrees. At research 
universities, about a dozen PhDs are awarded on an annual basis to students writing about theoretical, public policy, or historical aspects of intelligence and it is not unusual for professors at these institutions to also author monographs, edited volumes or journal articles dealing with similar topics. There are also several professional schools that offer MA and occasionally BA degrees in some aspect of analysis, law enforcement intelligence or homeland security that are intended to equip students for a career as intelligence professionals. The number of intelligence programs has grown steadily in the last two decades (Coulthart and Crosston 2015). The US government has its own institution, the National Intelligence University (NIU), which is accredited by the Middle States Commission on higher education and is a member of the Consortium of Universities of the Washington, DC Metropolitan Area. The best known non-government professional school is probably Mercyhurst College, which offers a Research/Intelligence Analyst Program (RIAP) with both undergraduate and graduate courses and degrees designed specifically for intelligence analysts. Current professors in the RIAP program include retired or former members of the Office of the Director of National Intelligence, the Raleigh Police Department, the US Navy, the US Department of Energy, the National Drug Intelligence Center, the US State Department, the US Army, the CIA, the Federal Bureau of Investigation, Canada's Department of National Defense, the Turkish Policy Academy. There are also specialized programs. For instance, the Center for Nonproliferation Studies at the Middleburry Insitution of International Studies offers curricula designed to meet the need for analysts dealing with proliferation issues. Another example of a specialized program is Embry-Riddle Aeronautical University. It offers programs in intellgence and homeland security that focus on the aviation industry in particular, and transportation infrastructure in general.

\section{Relationship Between Researchers and Practitioners}

The fact that some of the leading figures in intelligence studies are former American intelligence officials and that US intelligence agencies often rely on specialists from academe to consult on various regional and technical matters suggests that the nexus between scholars and intelligence professionals is productive and serious. Academics often 
bring their expertise to intelligence agencies by serving on or even leading the National Intelligence Council, by helping to review National Intelligence Estimates or other products before dissemination, by providing research results on the analytic process, or by helping to conduct post-mortems in the aftermath of a failure of analysis. Intelligence agencies are not averse to extending temporary security clearances to faculty so that they can be "read-in" to analysis and data so that they can assess its accuracy and validity. In a comparative context, this really is a remarkable state of affairs. US intelligence agencies actually seek the expertise and advice of the academic community to enhance their analysis and to understand their mistakes.

Since the end of the Cold War, intelligence professionals have also increased their presence and activities on campus and within the larger academic community. Intelligence agencies maintain "in-residence" programs, whereby they detail senior professionals to leading programs in international relations and security studies so that they can serve as a liaison between scholars and the broader intelligence community, teach classes, and conduct their own research. Former intelligence professionals also have helped create entire curriculum and courses at leading universities, crafting educational programs with an eye towards introducing students to practical aspects of the art of intelligence (Dujmovic 2017). Junior analysts also have been attending various scholarly conferences and events related to their particular areas of responsibilities to better incorporate the latest research and perspectives into their work.

Surrounded by impressive security, protected by law and populated with tight-lipped officials, intelligence agencies are foreboding places that seem inaccessible, especially to scholars with an interest in history, current policy, or intelligence. The US intelligence community is no exception. Yet, once a scholar demonstrtes their expertise and willingness to make a constructive contribution to the national well-being, intelligence officials can actually be rather open about ongoing work and contemporary issues. This is not to suggest that scholars are simply given access to classified materials willy-nilly; highly sensitive information is only exposed to "outsiders" on a strict need-to-know basis. Nevertheless, interactions between scholars and intelligence professionals can yield even more precious 
insights about what it is like to work as an intelligence analyst and what the term "intelligence" means in a practical sense today. In exchange for some commentary or advice, the student of intelligence might be granted the opportunity to observe the subject of study from the inside, so to speak, an experience that places theory, history and policy in a new perspective.

\section{FORUM CONCLUSION (James J. Wirtz and Damien Van Puyvelde)}

Our comparative survey of the state of intelligence studies and the nature and scope of the interaction between intelligence professional and scholars in various national settings highlights how the field is shaped by diferent political contexts and strategic cultures, levels of academic interest, and the willingness of intelligence agencies to tap outside resources. This forum confirms and shows how the subfield of intellgience studies is diversifying because of growing interest and new contributions from scholars working beyond the Anglosphere. Collaboration between academics and intelligence officers is high in the United States and the United Kingdom, somewhat less extensive in France and Israel, and apparently limited in Spain, Romania and Japan. In France and Spain, intelligence studies appears to be on the upswing, while Japanese and Romanian initiatives remain limited, not least by historical legacies. Despite this disparatity, scholars in all national settings have smade significant contributions to the field. Indeed, the short list of Israeli scholars provided by Uri Bar-Joseph identifies several researchers who played a major part in defining the field itself. Nevertheless, our survey does suggest that common obstacles limit the development of intelligence studies. As a national endeavor, a vibrant intelligence studies community requires some sort of access to the subject of study, to intelligence managers, analysts and archives. Thus government transparency continues to shape the development of intelligence studies at a national level.

Strategic cutlure, sepcifically, whether or not there is a tradition of citizen involvment in government endeavors requiring technical or scientific expertise that is in short supply, seems to shape the interaction between intelligence professionals and scholars. US, British and Israeli intelligence agencies seem more willing to involve outside experts in their work, 
and for the most part, scholars in these states appear willing to lend their expertise to various government endeavors. In these countries, intelligence scholars do not seem to confront the same obstacles encountered by most social scientists when engaging with practitioners in government (Jentelson and Ratner 2011; Desch 2019). As these exchanges occur, trusted relationships emerge that allow parties to gain insight into "intelligence," which enrichs theoretical work and helps place empirical materials in a richer context. In other national settings, relationships between governments and civilians in general, or intelligence and citizens in particular, have either been arms-length or even downright adversarial. Strategic culture, however, cuts both ways. Scholars have to deem intelligence worthy of study, while intelligence professionals have to believe that academics have something important to say.

It is also apparent that in some national settings, scholars interested in intelligence studies lead a rather lonely existence. For most of the twentieth century, academics often found little of interest when it came to intelligence; they often saw things like espionage, intelligence analysis, couter-terrorism or covert operations as necessary evils that were best ignored and not dignified with serious consideration. Because intelligence studies is more of a consumer, rather than a producer, of theoretical insights and is not easly caught up in the winds of intellectual fashion, it is unlikely to attract large numbers of mainstream scholars who must meet the demands of their own disciplines and departments to advance in their careers. Universities or other types of research centers that have departments or programs that specialize in intelligence studies or closely related fields can be found in just about every national setting, but the quality of instruction they provide, the resources they have available and they opportunities they create vary greatly.

Intelligence studies also flourishes when scholars have access to archival materials. How access is granted varies. In some settings, it is systematic and part of a general effort to declassify government documents so scholars can better understand the general course of international affairs, the role of intelligene agencies in shaping international events, and to gain some insight into the development of intelligence estimates themselves. In other settings, access to information seems a bit more personalized. After they demonstrate their 
bona fides as serious scholars and honest brokers, access to archives, oral histories and even current officials and analysts can occur, leading to new or richer explanations of important events or issues in national histories. Of course in some settings, access to archives is a non-starter, which greatly reduces the attractiveness of intelligence studies as an academic endeavor. This type of limitation partly explains why the study of intelligence has, thus far, largely remained foused on national experiences in the Global North.

In an unexpected twist, our survey also sheds light on an issue of growing importance to intelligence studies: a critical response to the dominance of cases, questions and concerns centered in the "Anglosphere" (Aldrich and Kasuku 2011). Instead of being fostered by intellectual, ideological or national bias, the "Anglosphere" might dominate the field because that is where its empirical materials are accessible. Studies of the performance and impact of intelligence on issues like warning, policy formulation and the creation of estimates in general often turn on exquisite details and nuanced interpretations of the interaction of facts, analysts' beliefs, and leaders receptivity. To undertake this kind of analysis requires highly detailed information that only exists in archives. Nevertheless, a logical advance for the field, and for the broader discipline of International Relations, would occur if French, Spanish, Romanian and Japanese scholars, for instance, could apply their mastery of the theoretical literature and lanauge skills to identify and explore important intelligence events in their respective countries.

\section{References}

ACADEMIA DE POLITIE. 2019. Accessed July 9, 2019. http://www.academiadepolitie.ro/ AdDock, Robert, Mark Bevir and Shannon C. Stimson. 2009. "A History of Political Science: How? What? Why?" In Modern Political Science: AngloAmerican Exchanges since 1880, edited by Robert Addock, 1-17. Princeton: Princeton University Press.

ALDRICH, RichARD J. 2001. The Hidden Hand: Britain, America, and Cold War secret intelligence. London: John Murray. 
— 2011. GCHQ: The Uncensored History of Britain's Most Secret Intelligence Agency. London: HarperCollins.

— 2013. "CIA history as a Cold War battleground. The forgotten first wave of agency narratives." In Intelligence Studies in Britain and the US, edited by Christopher Moran and Christopher J. Murphy, 19-46. Edinburgh: Edinburgh University Press.

ANDREW, CHRISTOPHER. 1977. "The British Secret Service and Anglo-Soviet Relations in the 1920s. Part I: From the Trade Negotiations to the Zinoviev Letter.” Historical Journal 20: 673-706.

_. 1977. "Whitehall, Washington and the Intelligence Services." International Affairs 53: 390-404.

_ 1995. For the President's Eyes Only. Secret Intelligence and the American Presidency from Washington to Bush. New York: HarperCollins.

ANDREW, CHRISTOPHER. 2009. Defend the Realm: The authorized history of MI5. Allen Lane: Penguin Books.

ANDREw, ChristoPHER AND Oleg GORDIEvSKy. 1990. KGB: The Inside Story of its Operations from Lenin to Gorbachev. New York: HarperCollins.

ANDREw, ChristoPHER AND VAsILY MithroKIn. 1999. The Mitrokhin Archive. The $K G B$ in Europe and the West. Allen Lane: Penguin.

ARCos, RubÉn. 2013. "Academics as Strategic Stakeholders of Intelligence Organizations: A View from Spain.” International Journal of Intelligence and CounterIntelligence 26: 332-346.

ARIGA, TsutaO. 1994. Nihon Riku Kaigun no Joho Kikou to Sono Katsudou. Tokyo: Kidai Bungeisha.

AsSEMBLEE NATiONALE. 2015. Loi $\mathrm{n}^{\mathrm{o}} 2015-912$ du 24 juillet 2015 relative au renseignement.

AsSOCIATION OF INTELLIGENCE History StUdies. 2019. Accessed July 9, 2019. https://intel2002.exblog.jp/i3/

Beard, CharLes. 2011. Ruzuberuto no Sekinin (The Responsibility of President Roosevelt). Tokyo: Fujiwara Shoten. 
Bergmam, Ronen. 2018. Rise and Kill First: The Secret History of Israel's Targeted Assassinations. New York: Random House.

BETTS, RiCHARD. 1978. “Analysis, War and Decision: Why Intelligence Failures Are Inevitable." World Politics 31: 61-89. . 1997. "Strategic Studies and its Critics.” World Politics 20: 593-605.

BLACK, IAN AND BENNY MORRIS. 1991. Israel's Secret Wars: The History of Israel's Intelligence Services. New York: Grove.

Blanco Navarro, José María and Gustavo Díaz Matey. 2015. "Presente y futuro de los estudios de inteligencia en España.” IEEE Document 11/2015. Accessed July 9, 2019. http://www.ieee.es/Galerias/fichero/docs_marco/2015/DIEEEM112015_EstudiosSeguridadEspana_JMBlanco-GustavoDiaz.pdf.

Bulinge, FrANCK. 2012. De l'espionnage au renseignement. La France à l'âge de l'information. Paris, Vuibert.

BUZAN, BARRY AND LENE HANSEN. 2009. The Evolution of International Security Studies. Cambridge: Cambridge University Press.

CAmpbell, Colin. 1986. "Secret C.I.A. Research on Campus: Harvard Reweighs Guidelines of 1970s.” New York Times, February 23, A32.

Central Intelligence Agency. 2019. "How to File a FOIA Request.” Accessed July 9, 2019. https://www.cia.gov/library/readingroom.foia_request.

CHIRU, IRENA. 2019. "National Intelligence Cultures" In The Conduct of Intelligence in Democracies: Processes, Practices, Cultures, edited by Florina C. Matei and Carolyn Halladay, 213-226. Boulder, CO: Lynne Rienner Publishers.

Chopin, Olivier And Benjamin Oudet. 2016. Renseignement et sécurité. Paris: Armand Colin.

ClARK, RICHARD. 2012. Intelligence Analysis. A Target-centric Approach. Washington D.C.: CQ Press.

Corera, Gordon. 2012. MI6: Life and Death in the British Secret Service. London: Phoenix.

CORMAC, RORY. 2013. Confronting the Colonies. British Intelligence and Counteinsurgency. London: Hurst. 
Coulthart, Stephen And Matthew Crosston. 2015. “Terra Incognita. Mapping American Intelligence Education Curriculum.” Journal of Strategic Security 8: 4668.

Cousseran, JeAn-Claude And PhilipPe Hayez. 2017. Leçons sur le renseignement, Paris: Odile Jacob.

CRISTESCU, RADU C. 2002. Serviciile Secrete din Romania si Scandalurile de Coruptie 1989-2001. Filipestii de Targ: Antet XX Press.

CRUMPTON, HENRY A. 2013. The Art of Intelligence: Lessons from a Life in the CIA's Clandestine Service. New York: Penguin.

DAVIES, PHILIP H. J. 2005. MI6 and the Machinery of Spying. London: Frank Cass.

DESCH, MichaEl C. Cult of the Irrelevant: The Waning Influence of Social Science on National Security. Princeton: Princeton University Press, 2019.

DiAmOnd, SigmOND. 1992. Compromised Campus. New York: Oxford University Press.

DíAZ Matey, Gustavo. 2010. “The Development of Intelligence Studies in Spain, International." Journal of Intelligence and CounterIntelligence 23: 748-765.

Díaz Matey, Gustavo And María Barco. 2015. "La formación en materias de inteligencia en España: Estado del arte a finales de 2015.” Revista UNISCI 41: $53-70$.

DíAZ-FERnÁnDEZ, ANTONio M. (Ed.). 2013. Diccionario LID de Inteligencia y Seguridad. Madrid: LID and Presidencia del Gobierno.

_ (Ed.). 2016. Conceptos Fundamentales de Inteligencia. Valencia: Tirant Lo Blanch.

- 2005. Los servicios de inteligencia españoles. Madrid: Alianza Editorial.

—. 2017. "De secretos a discretos: la política de apertura de los servicios de inteligencia occidentales." In Comunicación política en seguridad y defensa, edited by Rafael Martínez, 46-67. Barcelona: Cidob.

DujMOVIC, NichOLAS. 2011. “Getting CIA History Right: The Informal Partnership Between Agency Historians and Outside Scholars." Intelligence and National Security, 26: 229-245. 
- 2017. "Less is more, and more professional: reflections on building an 'ideal' intelligence program." Intelligence and National Security 32: 935943.

Dumitru, Irena. 2014. "Building an Intelligence Culture From Within: The SRI and Romanian Society." International Journal of Intelligence and CounterIntelligence 27: 569-589.

FERRIS, JOHN F. 1995. "Coming in from the Cold: The Historiography of American Intelligence, 1945-1990.” Diplomatic History 19: 87-115.

Filip, Valentn F. and Remus Stefureac. 2011. "The Dilemmas of Linking Romanian Intelligence, Universities, and Think Tanks." International Journal of Intelligence and CounterIntelligence 24: 711-732.

FoOT, M.R.D. 1966. SOE in France: An Account of the Work of the British Special Operations Executive in France, 1940-1944. London: Her Majesty Stationary Office.

Forcade, Olivier And Sebastien-Yves Laurent. 2019. Dans les secret du pouvoir. L'approche française du renseignement XVIIe-XXIe siècle. Paris: Nouveau Monde Editions.

ForCADE, OlIVIER AND MAURIVE VAÏSSE (eds). 2019. Le renseignement au début de la guerre froide, 1945-1955. Paris: La documentation française.

Galvache VALERO, Francisco. 2005. "La Formación de la Comunidad de Inteligencia Española: Un proceso en marcha." Revista Arbor 180: 183-205.

GELBER, YOAV. 1992. Growing a Fleur-de-Lis: The Intelligence Services of the Jewish Yishuv in Palestine 1918-1947. Tel Aviv: Ministry of Defense.

—. 2000. A Budding Fleur-de-Lis: Israeli Intelligence Services During the War of Independence, 1948-1949. Tel Aviv: Ministry of Defence Press.

GilboA, Amos AND EPHRAIM LAPI. 2012. Israel's Silent Defender: An Inside Look at Sixty Years of Israeli Intelligence. Jerusalem: Gefen.

Gill, Peter, StePhen MARrin AND MARK Phythian (eds). 2009. Intelligence:

Key Question sand Debates. London: Routledge.

GiLl, Peter, AND MARK PHYTHIAN. 2006. Intelligence in an Insecure World. Cambridge: Polity. 
Goodman, Michael. 2007. Spying on the Nuclear Bear: Anglo-American Intelligence and the Soviet Bomb. Stanford: Stanford University Press.

- 2014. The Official History of the Joint Intelligence Committee. Volume 1: From the approach of the Second World War to the Suez Crisis. London: Routledge.

Handel, Michael I. 1987. Strategic and Operational Deception in the Second World War. London: Frank Cass.

- 1988. Leaders and Intelligence. London: Frank Cass.

HAREL, ISSER. 1980. The German Scientists' Crisis. Tel Aviv: Maariv.

HARKABI, YeHOSHAFAT. 2015. The Intelligence as a National Institute. Tel Aviv: Maarachot.

Haruna, Mikio. 2000. Himitsu no Fairu - CIA no Tainichi Kousaku. Tokyo: Kyoudou Tsuushin.

Hastedt, Glenn P. 1991. "Towards the Comparative Study of Intelligence.” Conflict Quarterly 11: 55-72.

Herman, Michael. 1996. Intelligence Power in Peace and War. Cambridge: Cambridge University Press.

HiLsman, Roger. 1956. Strategic Intelligence and National Decisions. Westport, CT: Greenwood Press.

HINSLEy, HARRY. 1979. British Intelligence in the Second World War. Volume 1: Its Influence on Strategy and Operations. London: Her Majesty Stationery Office.

-1981. British Intelligence in the Second World War. Volume 2: Its Influence on Strategy and Operations. London: Her Majesty Stationery Office.

-1984. British Intelligence in the Second World War. Volume 3, Part 1: Its Influence on Strategy and Operations. London: Her Majesty Stationery Office. -1988. British Intelligence in the Second World War. Volume 3, Part 2: Its Influence on Strategy and Operations. London: Her Majesty Stationery Office. -1990. British Intelligence in the Second World War. Volume 4: Security and Counter-Intelligence. London, Her Majesty Stationery Office.

Hirajo, Hiromichi. 2011. Nichi Bei Himitsu Joho Kikan. Tokyo: Koudansha. 
HoleindRe, JeAn-VinCEnT AND BenJAmin Oudet. 2018. Les études sur le renseignement en France : Généalogie, structuration et propositions. Paris, IRSEM.

Institute OF $20^{\mathrm{TH}}$ Century Media, WASEDA UNIVERSiTy. 2019. “Intelligence.” Accessed July 9, 2019. http://www.waseda.jp/prj-intelligence/.

InStitute of NAtionAL SeCURITy StUdiES. 2019. Accessed June 25, 2019. https://www.inss.org.il/.

INTERNATIONAL STUDIES ASSOCIATION. 2019a. "Intelligence Studies Section - ISS

Governance and Leadership.” Accessed May 19, 2019.

https://www.isanet.org/ISA/Sections/ISS/Leadership.

_. 2019b. "Who we Are." Accessed May 19, 2019.

https://www.isanet.org/ISA/About-ISA.

ISRAEL ARCHIVES. 2019. Law 1955-21. Accessed June 25, 2019.

http://www.archives.gov.il/wp-

content/uploads/2016/03/\%D7\%97\%D7\%95\%D7\%A7-

\%D7\%94\%D7\%A8\%D7\%90\%D7\%9B\%D7\%99\%D7\%95\%D7\%A0\%D7\%99\%

D7\%9D-1955.pdf.

ISRAEL DEFENSE. 2019. February 4. Accessed June 25, 2019.

https://www.israeldefense.co.il/he/node/37347

ISRAEL Ministry OF DEFENSE. 2019. Archive. Accessed June 25, 2019.

http://www.archives.mod.gov.il/Pages/default.aspx.

ISRAEL MinistRy OF DEFENSE ARCHIVES. 2019. Declassified Documents of the Agranat Commission. Inquiry into the Events of the Yom Kippur War. Accessed June 25, 2019.

http://www.archives.mod.gov.il/pages/Exhibitions/agranat/agranat_commission.as p.

ISRAEl InTELLIGENCE Heritage AND COMMEMORATION CENTER. 2019. Accessed June 25, 2019. http://www.iicc.org.il/.

JACKSON, PETER. 2006. "Intelligence and the state: An emerging 'French school' of intelligence studies." Intelligence and National Security 21: 1061-1065. 
JAPAN SCIENCE AND TeChNOLOGy AgENCY. 2019. "Researchmap.” Accessed May 20, 2019. https://researchmap.jp/.

JAPANESE CABINET OfFICE. 2019a. "Cabinet Intelligence and Research Office.” Accessed June 20, 2019. https://www.cas.go.jp/jp/saiyou/pdf/panf_2018.pdf.

—. 2019b. "Information." Accessed June 20, 2019. http://www.moj.go.jp/content/001290851.pdf

JEFFEREY, KeITH. 2010. MI6: The Official History of the Secret Intelligence Service, 1909-1949. London: Bloomsbury.

Jentelson, Bruce W. AND Ely Ratner. 2011. "Bridging the Beltway-Ivory Tower Gap." International Studies Review 13: 6-11.

JERVIS, ROBERT. 2010. Why Intelligence Fails. Lessons from the Iranian Revolution and the Iraq War. Ithaca: Cornell University Press.

JoHnson, LOCH K. 2014. "The development of intelligence studies." In Routledge Companion to Intelligence Studies, edited by Robert Dover, Michael S. Goodman and Claudia Hillebrand. London: Routledge.

- 2015. A Season of Inquiry Revisited: The Church Committee Confronts America's Spy Agencies. Lawrence, KS: University Press of Kansas.

JOHNSON, LOCH K., ET AL. 2017. "Special Issue: The Teaching of Intelligence.” Intelligence and National Security 32: 881-1021.

KAM, EPHRAIM. 1987. Surprise Attack: The Victim's Perspective. Cambridge: Harvard University Press.

KatZ, SAMUEL M. 1992. Soldier Spies: Israeli Military Intelligence. Novato, CA: Presidio.

Kent, SHeRMAn. 1949. Strategic Intelligence for American World Policy. Princeton: Princeton University Press.

_. 1955. "The need for an intelligence literature." Studies in Intelligence 1: 1-11.

KitAOKA, HAJIME. 2003. Interijuensu Nyuumon. Tokyo: Keio UP.

KobaYASHI, Yoshiki. 2011. Interijyensu no Kisoriron. Tokyo: Tachibana Shobo.

_ 2015a. "Assessing Reform of the Japanese Intelligence

Community." International Journal of Intelligence and CounterIntelligence 28: 717-733. 
_. 2015b. "Intelligence Community Reform in Japan." 56th Annual Convention, International Studies Association, February 18.

KoKKai GiJiRoKu. 2019. “Proceedings of National Diet.” Accessed May 20, 2019. http://kokkai.ndl.go.jp/.

Kotani, Ken. 2011. "The US-Japanese Negotiations in 1941 and Signals Intelligence.” Joint Conference of the Association for Asian Studies, March 31.

- 2012. Interijyensu. Tokyo: Chikura Shobo.

LAPID, EPHRAIM. 2017. Academization of Intelligence Studies in Israel. Unpublished paper.

LASOEn, KenNeth. 2018. “Reactions to David Sherman's 'William Friedman and Harbor'.” Intelligence and National Security 33: 324-336.

LAurent, Sebastien-Yves. 2014. Atlas du renseignement: Géopolitique du pouvoir. Paris: Presses de Sciences Po.

LEVITE, ARIEL. 1987. Intelligence and Strategic Surprise. New York: Columbia University Press.

MaIOR, George C. 2012. "Managing Change: The Romanian Intelligence Service in the 21st Century.” International Journal of Intelligence and CounterIntelligence 25: 217-239.

Malalana-Ureña, Antonio And Lorena Moreno-PÉRez. 2017. "Investigar la Historia contemporánea en España: A la sombra de la Ley de Secretos Oficiales.” Historia Contemporánea 55: 669-702.

MARCHETTI, VICTOR AND JOHN D. MARKS. 1974. The CIA and the Cult of Intelligence. New York: Alfred A. Knopf.

Matei FlorinA, C. 2014a. "Balancing Democratic Civilian Control with Effectiveness of Intelligence in Romania: Lessons Learned and Best/Worst Practices Before and After NATO and EU Integration.” Intelligence and National Security 29: 619637.

_. 2014b. "Intelligence Education in New Democracies: The Case of Romania." Paper presented at the International Studies Association (ISA) Convention.

—. 2007a. "Reconciling Intelligence Effectiveness and Transparency: The Case of Romania.” Strategic Insights 6. Accessed 9 July, 2019. 
http://edocs.nps.edu/npspubs/institutional/newsletters/strategic\%20insight/2007/m ateiMay07.pdf.

_. 2007b. "Romania's IntelligenceCommunity: From an Instrument of Dictatorship to Serving Democracy." InternationalJournal of Intelligence and CounterIntelligence 20: 629-666.

MateI, Mihaela And Ionel NițU. 2012. "Intelligence Analysis in Romania's SRI: The Critical "Ps"-People, Processes, Products." International Journal of Intelligence and CounterIntelligence 25: 700-726.

Manningham-Buller, ElizA. 2012. Securing Freedom. London: Profile.

MAOZ, ZEEV. 2006. Defending the Holy Land: A Critical Analysis of Israel's National Security and Foreign Policy. Ann Arbor: University of Michigan Press.

MASTERMAn, JOHn. 1972. The double cross system in the war, 1939-1945. New Haven, CT: Yale University Press.

MEIR Amit InTELLIGENCE AND TERRORISM InFORMATION CENTER. 2019a. Accessed June 25, 2019. https://www.terrorism-info.org.il/en/news-terrorism-israeli-palestinianconflict-march-13-march-19-2019/.

—.2019b. Accessed June 25, 2019. https://www.terrorism-info.org.il/en/spotlightiran.

—. 2019c. Accessed June 25, 2019. https://www.terrorism-info.org.il/he/21152/. Ministere DES ARMEES. 2019. “Interaxions.” Accessed July 10, 2019. https://www.defense.gouv.fr/dgse/tout-le-site/interaxions.

Moran, Christopher And CHristopher Browning. 2018. "REF impact and the discipline of politics and international studies.” British Politics 13: 249-269.

Moran, Christopher. 2011. “The Pursuit of Intelligence History: Methods, Sources, and Trajectories in the United Kingdom." Studies in Intelligence 55: 33-55.

- 2012. Classified: Secrecy and the State in Modern Britain. Cambridge: Cambridge University Press.

MORAn, Christopher R. AND CHRISTOPHER J. MurPHy. 2013. Intelligence Studies in Britain and the US. Edinburgh: Edinburgh University Press.

Morgenstern, George. 1999. Shinjuwan (Pearl Harbor). Tokyo: Kinseisha 1999. 
Moyano, Manuel, José Manuel Gaet and Pedro Rivas. 2014. “Estudios sobre Inteligencia en la Academia Española: un balance retrospectivo a través de las tesis doctorales (1976-2012)." Revista Eletrônica de Biblioteconomia e Ciência da Informação 19: 213-234.

NaIKAKU Joho ChOuSA SiTsu. 2009. Waga Kuni no Joho Kinou, 24 February. Accessed July 7, 2019. https://www.kantei.go.jp/jp/singi/ampobouei2/dai4/siryou1.pdf.

NAKANISHI, TERUMASA AND Ken KOTANI (eds). 2007. The Century of Intelligence. Intelligence and International History in the 20 ${ }^{\text {th }}$ Century. Tokyo: Chikura Shobo. NAKANO KoyUUKAI. 1978. Rikugun Nakano Gakko. Tokyo: Hara Shobo.

NAtional ARChives of JAPAN. 2019. "Japan Center for Asian Historical Records.” Accessed July 7, 2019. https://www.jacar.go.jp/english/index.html.

NATIONAL COMMISSION ON TERRORIST ATTACKS UPON THE UNITED STATES. 2004. Final Report. New York: W.W. Norton.

National InTELligence BoARD. 2002. “Iraq's Continuing Programs for Weapons of Mass Destruction,” NIE 2003-16HC. Accessed July 10, 2019. https://documents.theblackvault.com/documents/Iraq/Iraq-smd-nie-01-2015.pdf. NihOn GaKUJYUtsu KaIGi. 2017. “Gunjiteki Anzenhosho Kenkyu ni Kansuru Seimei”, 24 March. Accessed July 10, 2019. http://www.scj.go.jp/ja/info/kohyo/pdf/kohyo23-s243.pdf.

OKAZAKI, HISAHIKO. 1980. Kokka to Joho. Tokyo: Bungei Shunjyuu.

OMAND, DAVID. 2011. Securing the State. London: Hurst.

Omand, David And Mark Phythian. 2018. Principled Spying. The Ethics of Secret Intelligence. Oxford: Oxford University Press.

OMORI, Yoshio. 2005. Nihion no Interijyensu Kikan. Tokyo: Bungei Shunjyu.

OtA, Fumio. 2005. Joho to Kokka Senryaku. Tokyo: Fuyo Shobo.

Parliament Of the United Kingdom. 1989. Security Services Act. . 1994. Intelligence Services Act.

Phythian, MARK. 2018. "Profiles in Intelligence: an Interview with Professor Christopher Andrew." Intelligence and National Security 32: 395-410.

—. 2018. "Profiles in Intelligence: an Interview with Professor Richard Aldrich." Intelligence and National Security 33: 939-973. 
Poirot, Jerome and Hugues Moutouh. 2018, Dictionnaire du renseignement. Paris: Perrin.

RANSOM, HaRry Howe. 1958. Central Intelligence and National Security. Cambridge: Harvard University Press.

—. 1980. "Being Intelligent About Secret Intelligence Agencies." American Political Science Review 74: 141-148.

RAVID, BARAK. 2010. "State archives to stay classified for 20 more years, PM instructs." Haaretz, July 28. Accessed July 12, 2019. https://www.haaretz.com/misc/articleprint-page/1.5152655.

Raviv, Dan AND Yossi Melman. 2014. Spies against Armageddon. New York: Levant Books.

RICHARDS, JULIAN. 2010. The Art and Science of Intelligence Analysis. Oxford: Oxford University Press.

Rimington, Stella. 2002. Open Secret: The Autobiography of the Former DiregtorGeneral of MI5. London: Arrow Books.

ROMANIAN INTELLIGENCE SERVICE. 2019. "Mihai Viteazul national intelligence academy." Accessed July 10, 2019. https://animv.ro/en.

Rovner, Joshua. 2011. Fixing the Facts: National Security and the Politics of Intelligence. Ithaca: Cornell University Press.

Samu, Maiwa'AZI Dandaura. 2017. Strategic Intelligence-Community Security Partnerships: Molding Partnerships in Conflict-Prone Regions. Lexington: Lexington Books.

Sanematsu, Yuzuru. 1980. Nichi Bei Joho Senki. Tokyo: Tosho Shuppan.

SASSA, ATSUYUKI. 2016. Watashi wo Torisugita Supaitachi. Tokyo: Bungei Shunjyu. SATO, MoRIo. 2012. Joho Sensou no Kyoukun. Tokyo: Fuyo Shobo.

SCOTT, LeN AND PETER JACKSON. 2004. "The Study of Intelligence in Theory and Practice." Intelligence and National Security 19: 139-169.

Siman Tov, DaVID AND Shay HershKovitz. 2013. Military Intelligence is Exposed: The First decade of the IDF Intelligence Branch. Tel Aviv: Ministry of Defense.

StATE OF ISRAEL. 1974. Additional partial Report: Notes and Appendices to the partial Report from Nisan 9, 5734. 
- 1975. Agranat Commission Report: Commission of Inquiry; Yom Kippur War. Tel Aviv: Am Oved.

StewART, GORDON. 1953. The Cloak and Dollar War. London: Lawrence and Wishart. StinetT, RoBert. 2001. Shinjuwan no Shinjitsu. Tokyo: Bungei Shunju.

SugITA, ICHIJ. 1987. Joho Naki Sensou Shidou. Tokyo: Hara Shobo.

TESHIMA, RyUUiCHI AND MASARU SATO. 2006. Interijuensu - Bukinaki Sensou. Tokyo: Gentousha.

Thomas, Gordon. 2015. Gideon Spies: The Secret Story of the Mossad. New York: St. Martin's.

Timofte, AleXANDRU R. 2003. Reforma Serviciului Roman de Informatii-Argumente si Fapte (Reform of the Romanian Domestic Intelligence Service - Arguments and Facts). Bucharest: Editura Academiei Nationale de Informatii.

Toland, JoHn. 1982. Shinjuwan Kougeki (Attack on Pearl Harbor). Tokyo: Bungei Shunju.

UedA, AtSUMORI. 2016. Senryakuteki Interijyensu Nyuumon. Tokyo: Namiki Shobo.

URBAN, MARK. 1996. UK Eyes Alpha: Inside British Intelligence. London: Faber and Faber.

VALERO, LARrY. 1993. “'We Need Our New OSS, Our New General Donovan, Now ...': The Public Discourse over American Intelligence, 1944-53.” Intelligence and National Security 18: 91-118.

VAN PUYVELDE, DAMIEN, AND SEAN CURTIS. 2016. "'Standing on the shoulders of giants': diversity and scholarship in Intelligence Studies." Intelligence and National Security 31: 1040-1054.

Winterbotham, F.W. 1974. The Ultra Secret. London: Weidenfeld and Nicolson. WIRTZ, JAMES J. 2014. “The Art of the Intelligence Autopsy.” Intelligence and National Security 29: 1-18.

_. 2018. "Review of Special Issue: Developing Intelligence Theory, Intelligence and National Security.” H-Diplo Article Review No. 815. http://tiny.cc/AR815

WohlstetTer, Roberta. 1962. Pearl Harbor: Warning and Decision. Stanford: Stanford University Press. 
Yamamoto, TAKetoshi. 1998. Tokumu Kikan no Bouryaku. Tokyo: Yoshikawa Koubunkan.

. 2013. GHQ no Kenetsu, Chohou, Senden kousaku. Tokyo: Iwanami.

—. 2017. Rikugun Nakano Gakko. Tokyo: Chikuma.

Yoshino, Jun. 2016. Joho Kikan wo Tsukuru. Tokyo: Bungei Shunjyu.

ZAMAN, RASHED UZ. 2009. "Strategic Culture: A "Cultural" Understanding of War." Comparative Strategy 28: 68-88.

ZEIRA, Eli. 1993. The October 73 War: Myth Against Reality. Tel Aviv: Yedioth Ahronoth. 